\title{
Effects of phytolithic rice-straw biochar, soil buffering capacity and pH on silicon bioavailability
}

\author{
Zimin Li (D) Dácil Unzué-Belmonte • \\ Jean-Thomas Cornelis • Charles Vander Linden • \\ Eric Struyf • Frederik Ronsse • Bruno Delvaux
}

Received: 9 November 2018 / Accepted: 25 February 2019

(C) Springer Nature Switzerland AG 2019

\begin{abstract}
Aims Supplying phytolith-rich biochar in agrosystems increases soil $\mathrm{pH}, \mathrm{CEC}$ and nutrient availability, adding to the impact of Si uptake on plant growth. Here we studied this specific impact as influenced by soil properties, and assessed the role of phytoliths to provide plant available $\mathrm{Si}$. Methods We used a young Cambisol and a highly weathered, poorly buffered, desilicated Nitisol. The biochars were produced from rice plants respectively enriched (Si+) and depleted (Si-) in Si. They had identical $\mathrm{pH}$ and
\end{abstract}

Responsible Editor: Honghua He.

Electronic supplementary material The online version of this article (https://doi.org/10.1007/s11104-019-04013-0) contains supplementary material, which is available to authorized users.

Z. Li $(\bowtie) \cdot$ C. V. Linden $\cdot$ B. Delvaux

Earth and Life Institute, Soil Science, Université catholique de Louvain (UCL), Croix du Sud 2 / L7.05.10,

1348 Louvain-La-Neuve, Belgium

e-mail: zimin.li@uclouvain.be

e-mail: zimin.li@hotmail.com

\section{Unzué-Belmonte $\cdot$ E. Struyf}

Ecosystem Management Research Group, Department of Biology, University of Antwerp, Universiteitsplein 1C, 2610 Wilrijk,

Belgium

J.-T. Cornelis

BIOSE department, Gembloux Agro-Bio Tech, University of

Liege, 5030 Gembloux, Belgium

F. Ronsse

Department of Biosystems Engineering, Faculty of Bioscience Engineering, Ghent University, Coupure Links 653,

B-9000 Ghent, Belgium nutrient contents, but largely differed in Si content $(51.3 \mathrm{~g}$ $\mathrm{Si} \mathrm{kg}{ }^{-1}$ in $\mathrm{Si}+\mathrm{vs} 0.3 \mathrm{~g} \mathrm{Si} \mathrm{kg}^{-1}$ in $\mathrm{Si}-$ ). We compared their effects to that of wollastonite $\left(\mathrm{CaSiO}_{3}\right)$ on the biomass and mineralomass of wheat plants in a soil:solution:plant device. The contents of soil bioavailable $\mathrm{Si}$ and biogenic $\mathrm{Si}$ were assessed through an original $\mathrm{CaCl}_{2}$ kinetic extraction and the DeMaster $\mathrm{Na}_{2} \mathrm{CO}_{3}$ alkaline dissolution, respectively.

Results The DeMaster technique dissolved Si from phytolith as well as from wollastonite. The soil buffering capacity $\left(\mathrm{cmol}_{\mathrm{c}} \mathrm{kg}^{-1}\right)$ was 31 in the Cambisol and 0.2 in the Nitisol. An identical supply of phytolithic biochar increased $\mathrm{pH}$ from 4.5 to 4.8 in the Cambisol, and from 4.8 to 7.4 in NI. It further increased the content of bioavailable $\mathrm{Si}$ (from 55 to $97 \mathrm{mg} \mathrm{kg}^{-1}$ in the Cambisol, and 36 to $209 \mathrm{mg} \mathrm{kg}^{-1}$ in the Nitisol), as well as plant $\mathrm{Si}$ uptake, biomass and $\mathrm{Si}$ mineralomass. That increase was largest in the Nitisol.

Conclusions The DeMaster technique did not specifically quantify the phytolith pool. This pool was the main source of plant available $\mathrm{Si}$ in both the Cambisol and Nitisol amended with phytolithic biochar. At identical phytolithic Si supply, however, soil $\mathrm{pH}$ and soil buffering capacity controlled the transfer of $\mathrm{Si}$ in the soil-plant system, which was largest in the poorly buffered Nitisol. The effect of phytolithic biochar on Si bioavailability was depending on soil constituents and properties, and thus on soil type.

Keywords Biochar Phytolith · Si bioavailability $\cdot \mathrm{pH}$. Soil buffering capacity 


\section{Introduction}

Natural soil desilication and crop harvesting contribute to the long-term removal of bioavailable silicon $(\mathrm{Si})$ (Guntzer et al. 2012) that can be challenged through Si fertilization. The primary source of Si for plant uptake is the reserve of weatherable lithogenic silicates (Alexandre et al. 1997; Henriet et al. 2008b; McKeague and Cline 1963). Their dissolution delivers aqueous $\mathrm{H}_{4} \mathrm{SiO}_{4}{ }^{0}$ (dissolved $\mathrm{Si}$ : DSi), aluminum (Al), iron $(\mathrm{Fe})$ and other solutes, which may form pedogenic alumino-silicates, $\mathrm{Al}$ and $\mathrm{Fe}$ oxides. These aluminosilicates can in turn dissolve depending on $\mathrm{H}_{4} \mathrm{SiO}_{4}{ }^{0}$ activity (Garrels and Christ 1965; Kittrick 1977). With advanced desilication and Si depletion, $\mathrm{Al}$ and Fe oxides accumulate in highly weathered soils. DSi can be taken up by plant roots, translocated to transpiration sites in plant shoots (Jones and Handreck 1965) where it polymerizes as amorphous biogenic $\mathrm{Si}$ (BSi), called phytolith, which returns to soil within plant residues (Smithson 1956). BSi minerals readily dissolve at common soil solution pH (Fraysse et al. 2006, 2009; Koning et al. 2002), and replenish the DSi pool. The biological pumping of Si thus alleviates soil desilication in highly weathered soils (Lucas 2001; Lucas et al. 1993; Meunier et al. 1999; Riotte et al. 2018).

Under natural or semi-natural vegetation, the BSi pool may progressively become the most important source of DSi along a global soil weathering gradient with increasing depletion of lithogenic and pedogenic silicates (Lucas et al. 1993; Cornelis and Delvaux 2016). In agrosystems, however, crop harvesting disrupts $\mathrm{Si}$ biocycling because of Si exportation through phytomass removal and water flows (Guntzer et al. 2012; Haynes 2017; Keller et al. 2012; Meunier et al. 2008; Vandevenne et al. 2012). Thus, soil weathering and crop harvesting contribute to soil desilication that may reduce crop yield since Si increases plant photosynthetic activity and tolerance against biotic and abiotic stresses (Belanger 1995; Epstein 1994; Exley 1998). Enhancing Si biocycling through Si fertilization thus presents a major agronomic interest in croplands established on highly weathered soils. Silicate slag and minerals can be used, but they are expensive, limited worldwide and poor in DSi, and they may contain toxic elements (Berthelsen et al. 2001; Datnoff and Heckman 2014; Haynes 2014; Haynes et al. 2013). Over 250 million farmers in the tropics commonly use burnt phytomass to challenge the infertility of highly weathered soils. The supply of pyrolyzed biomass increases $\mathrm{pH}, \mathrm{CEC}$ and the contents of organic carbon and plant nutrients (Glaser et al. 2002; Laird et al. 2010; Lehmann and Joseph 2015; Liang et al. 2006; Sohi et al. 2010). Plantderived phytoliths concentrate in biochar particles (Wang et al. 2018; Xiao et al. 2014). Biochar is thus a potential Si fertilizer (Glaser et al. 2002; Houben et al. 2014) able to deliver DSi (Li et al. 2018) because of the increase in phytolith solubility after pyrolysis (UnzuéBelmonte et al. 2016; Xiao et al. 2014). Furthermore, biochar has a liming effect (Glaser et al. 2002) promoting phytolith dissolution the rate of which increases by 2 orders of magnitude from $\mathrm{pH} 4$ to 8 (Fraysse et al. 2009). The increase in Si bioavailability due to liming (Keeping et al. 2017; Klotzbücher et al. 2018; Haynes 2019) must depend, however, on $\mathrm{pH}$ increase and thus soil buffering capacity, hence on soil constituents and weathering stage. This is unknown, despite that these soil properties can control the ability of phytolithic biochar to increase $\mathrm{Si}$ bioavailability, and enhance $\mathrm{Si}$ biocycling. Here we study the specific effects of phytolithic biochar to supply bioavailable $\mathrm{Si}$ in soil:solution:plant systems involving a Cambisol and a Nitisol differing in weathering stage, soil constituents and buffering capacity.

\section{Materials and methods}

Soils and external Si sources

The two selected soils differ in weathering stage. They key out as a Dystric Cambisol (CA) and a Rhodic Nitisol (NI) in the WRB system (IUSS 2014). Under a climax beech forest (Fagus sylvatica), the Cambisol CA (Grand Han, Belgium) is moderately weathered; it derives from Famenian schist under humid temperate conditions, and contains weatherable $\mathrm{Mg}, \mathrm{K}$ and $\mathrm{Na}$ silicates (Mg-chlorite, feldspar, oxidized biotite, albite) as well as quartz, vermiculite, smectite and kaolinite (Titeux and Delvaux 2009). Without any vegetation cover, NI is a buried paleosol from the quarry of Transinne (Belgium) formed from Early Devonian bedrock under humid tropical paleo-conditions. The Nitisol (NI) is highly weathered; it contains kaolinite, Fe oxides, muscovite and quartz (Thiry et al. 2006). In both soils CA and NI, we sampled the topsoil $(00-20 \mathrm{~cm}$ depth). Soil samples were air-dried and sieved at 
$2 \mathrm{~mm}$. Further experiments and analyses were all carried out on the fine earth fraction $(f \leq 2 \mathrm{~mm})$.

Si sources

The wollastonite (Wo) $\left(\mathrm{CaSiO}_{3}\right)$ was used as a reference non-biochar silicon source, which was provided by R.T Vanderbilt Company, Inc., Norwalk, CT, USA. We used powdered VANSIL ® W-10 that contains wollastonite $(\leq 99 \%)$ and quartz $(0.8-1.3 \%)$.

The Si-enriched and Si-depleted biochars ( $\mathrm{Si}+$ and $\mathrm{Si}$-) were produced from rice straws. Rice seeds (Oryza sativa subsp. indica IR64 from IRRI, Philippines) were germinated on a polystyrene plate floating on a Yoshida nutrient solution (Yoshida 1981) in 10 plastic tanks each of $25 \mathrm{~L}$. Three seeds were placed in each of the 30 holes perforating the plate. $\mathrm{Si}+$ and $\mathrm{Si}$ - rice plants were each produced in 5 respective tanks. After one week, the solutions for $\mathrm{Si}+$ plants were enriched with aqueous $\mathrm{H}_{4} \mathrm{SiO}_{4}{ }^{0}$ at a concentration of $40 \mathrm{mg} \mathrm{L}{ }^{-1} \cdot \mathrm{H}_{4} \mathrm{SiO}_{4}{ }^{0}$ was prepared through dissolving $\mathrm{Na}_{2} \mathrm{SiO}_{3} \cdot 5 \mathrm{H}_{2} \mathrm{O}$, and further leaching on an $\mathrm{H}^{+}$cation exchanger (Amberlite $\left.{ }^{\circledR} I R-120\right)$ to fix $\mathrm{Na}^{+}$ions until the threshold level of $\mathrm{Na}^{+}$was below $10^{-2} \mathrm{mM} \mathrm{Na}$ (Henriet et al. 2006). $\mathrm{Si}+$ and $\mathrm{Si}-$ nutrient solutions were renewed every week. After two weeks, the seedlings were thinned to one plant per hole. $\mathrm{pH}$ was adjusted daily to $5.0-5.3$ by using $2 \mathrm{M} \mathrm{KOH}$ or $\mathrm{HCl}$. $\mathrm{Si}+$ and $\mathrm{Si}-$ plants grew in greenhouse controlled conditions: $80 \%$ relative humidity, $28 / 25^{\circ} \mathrm{C}$ day/night, $12 \mathrm{~h}$ photoperiod with $360 \mu \mathrm{mol} \mathrm{m} \mathrm{m}^{-2} \mathrm{~s}^{-1}$ light intensity. After 12 weeks, the plants were harvested. The aboveground biomass was measured fresh, then dry after 7 days at $55{ }^{\circ} \mathrm{C}$. The biochars were obtained from, respectively, $\mathrm{Si}+$ and $\mathrm{Si}$-rice straws according to a slow pyrolysis procedure as described by Ronsse et al. (2013). Dried straws (2 cm fragments) were placed in a vertical, tubular, stainless steel reactor $(\mathrm{d} \times \mathrm{L}=3.8 \times 30 \mathrm{~cm})$, and further pyrolyzed at a heating rate of $17{ }^{\circ} \mathrm{C} \mathrm{min}^{-1}$ up to $500{ }^{\circ} \mathrm{C}$. The reactor was maintained at $500{ }^{\circ} \mathrm{C}$ for $60 \mathrm{~min}$, and then progressively cooled. Nitrogen was continuously supplied to remove gases and tars produced during the pyrolysis process. Biochar yields were calculated as the mass ratio of biochar to the dried RS used for the pyrolysis process. The Si-enriched $(\mathrm{Si}+)$ and $\mathrm{Si}$ depleted $(\mathrm{Si}-)$ biochars were passed through a $0.154 \mathrm{~mm}$ sieve prior to experimental use.
Soil:Amendment mixtures

Soil:Wollastonite (Cambisol:Wollastonite CA:Wo and nitisol:Wollastonite NI:Wo)

Wollastonite (Wo) was added in triplicates at the rate of $3.2 \mathrm{~g} \mathrm{Wo} \mathrm{kg}^{-1}$ soil to CA and NI, resulting in supplying $810 \mathrm{mg} \mathrm{Si} \mathrm{kg}^{-1}$ of soil.

Soil:Biochar (Cambisol:Biochar CA:Si+, CA:Si-; nitisol:Biochar NI:Si+, NI:Si-)

Biochar materials were added to soils in triplicates at the rate of $15 \mathrm{~g}$ biochar per $\mathrm{kg}$ of soil resulting in supplying $810 \mathrm{mg} \mathrm{Si}$ per kg of soil for both $\mathrm{CA}: \mathrm{Si}+$ and $\mathrm{Ni}: \mathrm{Si}+$, and $3 \mathrm{mg}$ Si per $\mathrm{kg}$ of soil for both CA:Si- and NI:Si-. These application rates fall within the range of field applications (Liu et al. 2013; Ma and Takahashi 2002).

\section{Basic analyses of soils, amendments and soil:Amendment mixtures}

Elemental contents $(\mathrm{Si}, \mathrm{Al}, \mathrm{Fe}, \mathrm{K}, \mathrm{Ca}, \mathrm{Na}$ and $\mathrm{Mg}$ ) in soils, amendments and soil:amendment mixtures were determined by inductively coupled plasma/atomic emission spectrometry (ICP-AES, Jarrell Ash Iris Advantage) after alkaline fusion using Li-metaborate $+\mathrm{Li}$ tetraborate at $1000{ }^{\circ} \mathrm{C}$, followed by ash dissolution with concentrated $\mathrm{HNO}_{3}$ (Chao and Sanzolone 1992). The contents of major alkaline and alkaline-earth cations in soils were summed up to compute the total reserve in bases (TRB) (Herbillon 1986). The contents of C and N (and $\mathrm{H}$ for rice straw and biochar) were measured using a Flash 2000 Elemental Analyzer (Thermo Fisher Scientific, Waltham, MA, USA). $\mathrm{pH}$ was measured in $\mathrm{H}_{2} \mathrm{O}$ and $1 \mathrm{M} \mathrm{KCl}$ using $5 \mathrm{~g}: 25 \mathrm{~mL}$ suspensions respectively for soils but only in water for biochar materials. The cation exchange capacity (CEC) and content of exchangeable cations were determined on soil and soil:amendment using $1 \mathrm{M} \mathrm{CH}_{3} \mathrm{COONH}_{4}$ buffered at pH 7 (Chapman 1965). The buffering capacity was measured by supplying metered additions of $\mathrm{OH}^{-}$ions in the form of $\mathrm{CaCO}_{3}$ equivalent doses using a solid:liquid ratio of 1:5. Suspensions were shaken overnight, then opened to ambient air. They were stirred intermittently, and the $\mathrm{pH}$ was measured after equilibration with atmospheric $\mathrm{CO}_{2}$. The identification of crystalline soil minerals was confirmed by X-ray diffraction (XRD) on powder soil samples using $\mathrm{Cu} K \alpha$ radiation in 
a Bruker Advance diffractometer. Scanning Electron Microscopy coupled with Energy Dispersive X-ray analysis (SEM-EDX) were performed on rice straw and biochar without any chemical pretreatment using a field emission gun SEM (FEG-SEM; Zeiss Ultra55) equipped with an EDX system (Jeol JSM2300 with a resolution $<129 \mathrm{eV}$ ), and operating at $15 \mathrm{keV}$ with a working distance of $8 \mathrm{~mm}$. The acquisition time of the EDX spectra lasted $100 \mathrm{~s}$ with a probe current of $1 \mathrm{nA}$.

\section{Specific Si extractions}

The contents of alkaline- and $\mathrm{CaCl}_{2}$-extractable $\mathrm{Si}$ were determined through kinetic extractions in triplicate. (I) Alkaline extractable $\mathrm{Si}$ content $\left(\mathrm{Si}_{\mathrm{alk}}\right)$ was determined to assess biogenic silica (BSi) minerals in soils (DeMaster 1981; Koning et al. 2002; Saccone et al. 2006). Thirty $\mathrm{mg}$ of dried soil $(<2 \mathrm{~mm})$ was mixed in $40 \mathrm{ml}$ of $\mathrm{Na}_{2} \mathrm{CO}_{3} 0.1 \mathrm{M}, \mathrm{pH}=11.2$, and digested for $5 \mathrm{~h}$ at $85^{\circ} \mathrm{C}$. One $\mathrm{ml}$ of extraction solution was taken at 1,2 , 3, 4 and $5 \mathrm{~h}$, then neutralized and acidified by adding $100 \mu \mathrm{l}$ of $\mathrm{HNO}_{3} 7 \mathrm{M}$ to analyze dissolved Si using ICPAES. The extracted $\mathrm{Si}\left(\mathrm{mg} \mathrm{g}^{-1}\right)$ was plotted against time (DeMaster 1981). Corrections for the simultaneous alkaline dissolution of amorphous and crystalline Si using time course extractions (DeMaster 1981; Koning et al. 2002), assume that (a) most of the amorphous pool is dissolved within the first $2 \mathrm{~h}$ of extraction, and (b) the clay minerals release $\mathrm{Si}$ at a much slower and constant rate during the whole extraction. The concentration of $\mathrm{Si}_{\text {alk }}$ is determined by the intercept of the linear part of the plot, using the $\mathrm{lm}$ function of the R programming language to fit a first-order kinetic model (Cornelis et al. 2011). (II) $\mathrm{CaCl}_{2}$-extractable $\mathrm{Si}$ content $\left(\mathrm{CaCl}_{2}-\mathrm{Si}\right)$ is considered to assess the bioavailable Si pool in soils (Haysom and Chapman 1975; Sauer et al. 2006). It was measured through an original kinetic extraction using a solid:liquid ratio $5 \mathrm{~g}: 50 \mathrm{~mL}\left(0.01 \mathrm{M} \mathrm{CaCl}_{2}\right)$ in $100 \mathrm{~mL}$ polyethylene cups shaken at $25^{\circ} \mathrm{C}$. The $1: 10$ solid:liquid ratio was kept constant using replicates for both the extraction and analysis. At each time step $(6 \mathrm{~h}$, 12 h, 1 day, 2 days, 4 days, 8 days, 16 days, 32 days, 64 days and 128 days), the collected suspension $(50 \mathrm{~mL})$ was centrifuged at $3000 \mathrm{~g}$ for $20 \mathrm{~min}$. The supernatant $(40 \mathrm{~mL})$ was filtered and separated in two aliquots of $20 \mathrm{~mL}$ to measure, respectively, $\mathrm{pH}$ and solutes concentrations. The latter extract was acidified by adding $100 \mu \mathrm{l}$ of $\mathrm{HNO}_{3} 7 \mathrm{M}$, then stored in darkness at $4{ }^{\circ} \mathrm{C}$ prior to further analyses.
Experimental system

Wheat seeds (Triticum aestivum L.) were sterilized with $\mathrm{NaOCl}$ for 10 min and washed three times using deionized water. They germinated on a polystyrene plate floating in a $700 \mathrm{~mL}$ polypropylene beaker in a soil:solution system including $500 \mathrm{~mL}$ deionized water and $10 \mathrm{~g}$ of, respectively, soil (CA, NI) and soil:amendment mixtures (CA:Wo, CA:Si+, CA:Si-; NI:Wo, NI:Si+, NI:Si-). After one week, both the $\mathrm{pH}$ and DSi content were measured in the liquid phase of the solid:liquid device, before planting (solid= soil or soil:amendment mixture). Wheat seedlings and further plantlets grew under greenhouse conditions: 25/ $20{ }^{\circ} \mathrm{C}$ day/night, $70 \%$ relative humidity, and $12 \mathrm{~h}$ photoperiod with $360 \mu \mathrm{mol} \mathrm{m} \mathrm{m}^{-2} \mathrm{~s}^{-1}$ light intensity. Ten seedlings after germination were kept for growing in greenhouse till harvest. The ten seedlings with approximately $5 \mathrm{~cm}$ roots were randomly planted in each treatment. After 4 days, 5 out of these 10 were selected. After 32 days, wheat shoots were collected and washed using deionized water, $1 \mathrm{M} \mathrm{HCl}, 70 \%$ ethanol, and further rinsed with Milli-Q water to avoid any contamination (Kelly 1990). Shoots were dried at $55{ }^{\circ} \mathrm{C}$ for 7 days to weigh the dry matter (DM). The dried plant materials were further analyzed following the procedures described above for rice straw.

\section{Data analyses}

Statistical analyses were performed using SPSS 24.0 software. The effects of the various treatments in all Tables and Figures were analyzed through a one-way analysis of variance (ANOVA) and a non-parametric (Kruskal-Wallis) test at the level of $p<0.05$.

Efficiency of Si release $\left(R_{S i}\right)$ The efficiency of Si release $\left(R_{S i}\right)$ from the soil:amendment mixture was assessed using the time release of $\mathrm{CaCl}_{2}$ extractable $\mathrm{Si}$ content following Eq 1:

$R_{S i}=\frac{[\mathrm{CaCl} 2-\mathrm{Si} \text { in soil : amendment }]-[\mathrm{CaCl} 2-\mathrm{Si} \text { in soil }]}{\text { Total } \mathrm{Si} \text { input from amendment }} \times 100$

where $\mathrm{CaCl}_{2}$-Si was the amount (mg) of Si released after $128 \mathrm{~d}$ respectively in each pot; total $\mathrm{Si}$ input from amendment was the amount (mg) of Si brought by biochar (Si- and $\mathrm{Si}+$ ) and Wo in each pot. 


\section{Results}

Properties of rice-straws, biochars and wollastonite (wo) The $\mathrm{Si}-$ and $\mathrm{Si}+$ rice-straws differed in their respective biomasses, $\mathrm{O}$ contents, ash percentages and $\mathrm{Si}$ contents (Table 1). The biochar yield, as defined in Table 1, was significantly lower for $\mathrm{Si}$ than for $\mathrm{Si}+$. The contents of $\mathrm{K}, \mathrm{Ca}, \mathrm{Na}, \mathrm{Mg}$ and $\mathrm{Si}$ differed significantly between Wo and biochars (Table 1). The Si- and $\mathrm{Si}+$ biochars also differed in their respective $\mathrm{O}$ concentrations, ash percentages and $\mathrm{Si}$ contents. Following pyrolysis, the $\mathrm{O}: \mathrm{C}$ ratio markedly decreased by 5 - and 9-fold in Si- and $\mathrm{Si}+$ biochars, respectively. The SEM micrographs and related EDX spectra further illustrated that Si-depleted rice-straw (Fig. 1a, e) and Si- biochar (Fig. 1c, g) were free of phytoliths. In contrast, ricestraw enriched in Si contained dumbbell-shaped, fine silt-sized phytoliths (Fig. 1b, f) whereas $\mathrm{Si}+$ biochar contained phytoliths in abundance (Fig. 1d, h).
Properties of soils and soil:Amendment mixtures Table 2 showed that the Total Reserve in Bases (TRB) amounted to $144 \mathrm{cmol}_{\mathrm{c}} \mathrm{kg}^{-1}$ in the Cambisol CA and $107 \mathrm{cmol}_{\mathrm{c}} \mathrm{kg}^{-1}$ in the Nitisol NI. X-ray diffraction (XRD) data (not shown) confirmed previous identifications. In CA, XRD data showed that primary silicates were quartz, oxidized biotite, feldspar, chlorite and albite. CA clay minerals consisted of kaolinite and an assemblage of 2:1:1 and 2:1 clay minerals involving chlorite, illite, vermiculite and smectite. The Nitisol (NI) contained muscovite and kaolinite phyllosilicates as well as quartz, rutile (not shown), and Fe oxide. In NI, K was by far the largest dominant cation in TRB (Table 2). Biochar application did not result in a significant increase of TRB $(p<0.05)$. However, Wo application generated a marked increase of total $\mathrm{Ca}$ content $\left(\mathrm{cmol}_{\mathrm{c}} \mathrm{kg}^{-1}\right)$ : from 2.7 to 8.1 in $\mathrm{CA}$ and from 1 to 8.4 in NI.

Table 1 Selected properties of Si-depleted, Si-enriched rice-straws and their respective biochars (Si-, Si+), and wollastonite (Wo): average values of their respective elemental contents; $\mathrm{H}: \mathrm{C}, \mathrm{O}: \mathrm{C}, \mathrm{C}: \mathrm{N}$ atomic ratios, biochar ash content and yield + , and $\mathrm{pH}-\mathrm{H}_{2} \mathrm{O}$

\begin{tabular}{|c|c|c|c|c|c|c|c|}
\hline \multicolumn{2}{|l|}{ Properties } & \multicolumn{2}{|l|}{ Rice straw } & \multicolumn{2}{|l|}{ Biochar } & \multirow[t]{2}{*}{ Wo } & \multirow[t]{2}{*}{ ANOVA $p$} \\
\hline & & Si depleted & Si enriched & Si- & $\mathrm{Si}+$ & & \\
\hline $\mathrm{C}$ & $\mathrm{g} \mathrm{kg}^{-1}$ & 396.1 & 384.6 & 520.0 & 486.5 & nd & nd \\
\hline $\mathrm{H}$ & & 55.0 & 54.6 & 22.6 & 20.6 & nd & nd \\
\hline $\mathrm{O}$ & & $391.8^{*}$ & $350.6^{*}$ & $106.2 * * *$ & $57.5^{* * *}$ & nd & nd \\
\hline $\mathrm{N}$ & & 39.0 & 37.1 & 41.1 & 37.1 & nd & nd \\
\hline $\mathrm{H}: \mathrm{C}$ & & 0.1 & 0.1 & 0.04 & 0.0 & nd & nd \\
\hline $\mathrm{O}: \mathrm{C}$ & & 1.0 & 0.9 & 0.2 & 0.1 & nd & nd \\
\hline $\mathrm{C}: \mathrm{N}$ & & 10.2 & 10.4 & 12.6 & 13.2 & nd & nd \\
\hline K & $\mathrm{g} \mathrm{kg}^{-1}$ & 40.7 & 40.7 & 84.9 & $95.2 \mathrm{~A}$ & $1.1 \mathrm{~B}$ & $<0.001$ \\
\hline $\mathrm{Ca}$ & & 5.9 & 3.7 & $13.7 \mathrm{~B}$ & 11.6 B & $313.5 \mathrm{~A}$ & $<0.001$ \\
\hline $\mathrm{Na}$ & & 0.6 & 0.5 & $1.1 \mathrm{~A}$ & $1.3 \mathrm{~A}$ & $0.4 \mathrm{~B}$ & $<0.001$ \\
\hline $\mathrm{Mg}$ & & 5.9 & 4.9 & $16.5 \mathrm{~A}$ & $14.1 \mathrm{~A}$ & $11.0 \mathrm{~B}$ & 0.003 \\
\hline $\mathrm{Si}$ & & $0.9 * * *$ & $16.3 * * *$ & $0.3 \mathrm{C}$ & $51.3 \mathrm{~B}$ & $235.4 \mathrm{~A}$ & $<0.001$ \\
\hline Ash & $\%$ & $11.8^{* *}$ & $17.3 * *$ & $31.0 *$ & $39.6^{*}$ & nd & nd \\
\hline Yield $\dagger$ & $\%$ & nd & nd & $31.0 *$ & $36.4 *$ & nd & nd \\
\hline Biomass (Dry weight) & $\mathrm{g}_{\text {plant }}^{-1}(n=300)$ & $3.5 * *$ & $6.7 * *$ & nd & nd & nd & nd \\
\hline $\mathrm{pH}_{\mathrm{H} 2 \mathrm{O}}$ & & nd & nd & $10.6 \mathrm{~A}$ & $10.7 \mathrm{~A}$ & $9.1 \mathrm{~B}$ & 0.02 \\
\hline
\end{tabular}

The average values $\left(\mathrm{n}=3\right.$ ) of $\mathrm{pH}-\mathrm{H}_{2} \mathrm{O}$ and contents of $\mathrm{K}, \mathrm{Ca}, \mathrm{Na}, \mathrm{Mg}$ and $\mathrm{Si}$ are presented with different uppercase letters (A, B, C) between amendments ( $\mathrm{Si}-, \mathrm{Si}+$ and $\mathrm{Wo}$ ) at the $\mathrm{p}<0.05$ level of confidence according to Tukey's mean separation test. $p$ values within the various amendments are given through a one-way analysis of variance (ANOVA)

nd: not determined

$\dagger$ : The biochar yield is the ratio of the mass of biochar to the initial dry mass of rice straw expressed as a percentage

Asterisks $(* p<0.05 ; * *<0.01 ; * * p<0.0001)$ indicates significant difference between $\mathrm{Si}$ - and $\mathrm{Si}+$ (rice straw) or $\mathrm{Si}$ and $\mathrm{Si}+(\mathrm{biochar})$ 

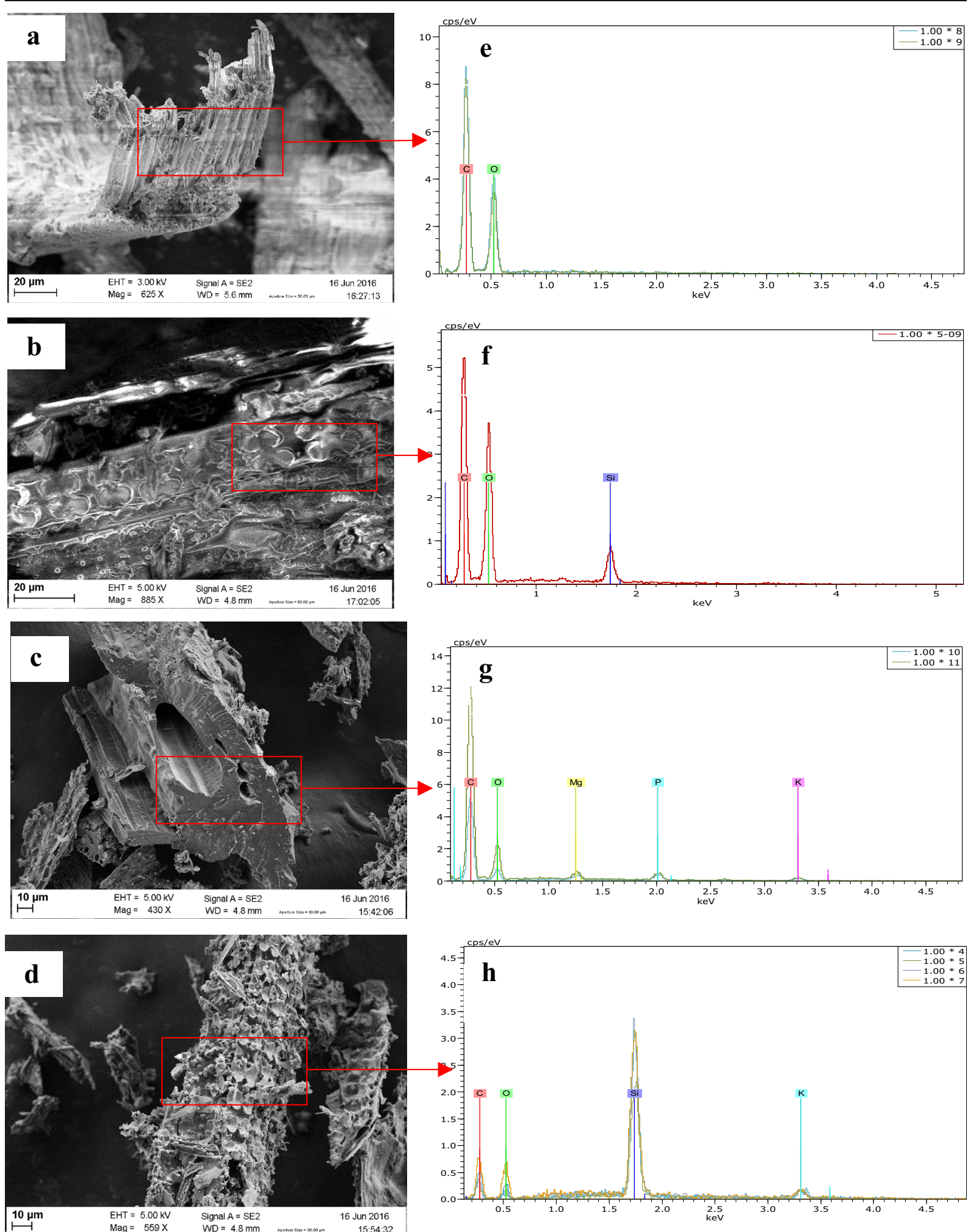

Fig. 1 SEM images of (a-b) rice straw materials Si-depleted (a), and Si-enriched (b), (c-d) biochar particles Si- (c) and $\mathrm{Si}+(\mathbf{d})$. Corresponding EDX spectra performed on (e-f) rice straw materials Si-depleted (e) and Si-enriched (f), (g-h) biochar particles $\mathrm{Si}-(\mathbf{g})$ and $\mathrm{Si}+(\mathbf{h})$, demonstrating the presence of phytoliths in $\mathrm{Si}+$ 
Table 2 Total average contents $(n=3)$ of selected major elements; Total Reserve in Bases (TRB), and $\mathrm{Si} /(\mathrm{Al}+\mathrm{Fe})$ atomic ratio in $\mathrm{CA}$ and NI, CA:Si-, CA:Si+, CA:Wo; NI, NI:Si-, NI:Si+, NI:Wo

\begin{tabular}{|c|c|c|c|c|c|c|c|c|c|c|}
\hline \multirow[t]{2}{*}{ Soils } & \multirow[t]{2}{*}{ Treatments } & \multicolumn{4}{|c|}{ Total elements } & \multirow[t]{2}{*}{${ }^{*}$ TRB } & \multicolumn{3}{|c|}{ Total elements } & \multirow[t]{2}{*}{$\mathrm{Si} /(\mathrm{Al}+\mathrm{Fe})$} \\
\hline & & $\begin{array}{l}\mathrm{Ca} \\
\mathrm{cmol}_{\mathrm{c}} \mathrm{kg}^{-1}\end{array}$ & K & $\mathrm{Na}$ & $\mathrm{Mg}$ & & $\begin{array}{l}\mathrm{Si} \\
\mathrm{g} \mathrm{kg}^{-1}\end{array}$ & $\mathrm{Al}$ & $\mathrm{Fe}$ & \\
\hline \multirow[t]{4}{*}{ Cambisol } & Soil CA & $2.7 \mathrm{~d}$ & $59.6 \mathrm{c}$ & $21.6 \mathrm{a}$ & $60.2 \mathrm{a}$ & $144 \mathrm{a}$ & $270.8 \mathrm{~b}$ & $87.4 \mathrm{~b}$ & $55.2 \mathrm{a}$ & $2.3 \mathrm{~b}$ \\
\hline & $\mathrm{CA}: \mathrm{Si}-$ & $4.2 \mathrm{~b}$ & $61.9 \mathrm{c}$ & $21.5 \mathrm{a}$ & $60.2 \mathrm{a}$ & $148 \mathrm{a}$ & $269.8 \mathrm{~b}$ & $84.1 \mathrm{~b}$ & $53.4 \mathrm{a}$ & $2.3 \mathrm{~b}$ \\
\hline & $\mathrm{CA}: \mathrm{Si}+$ & $3.8 \mathrm{c}$ & $61.2 \mathrm{c}$ & $21.0 \mathrm{a}$ & $59.6 \mathrm{a}$ & $146 \mathrm{a}$ & $272.5 \mathrm{~b}$ & $84.5 \mathrm{~b}$ & $54.9 \mathrm{a}$ & $2.3 \mathrm{~b}$ \\
\hline & CA:Wo & $8.1 \mathrm{a}$ & $58.8 \mathrm{c}$ & $21.6 \mathrm{a}$ & $59.2 \mathrm{a}$ & $148 \mathrm{a}$ & $274.2 \mathrm{~b}$ & $85.6 \mathrm{~b}$ & $54.9 \mathrm{a}$ & $2.3 \mathrm{~b}$ \\
\hline \multirow[t]{4}{*}{ Nitisol } & Soil NI & $1.7 \mathrm{e}$ & $82.9 \mathrm{a}$ & $8.4 \mathrm{~b}$ & $14.6 \mathrm{~b}$ & $108 \mathrm{~b}$ & $317.2 \mathrm{a}$ & $97.7 \mathrm{a}$ & $28.7 \mathrm{~b}$ & $2.7 \mathrm{a}$ \\
\hline & NI:Si- & $2.9 \mathrm{~d}$ & $75.3 \mathrm{~b}$ & $7.1 \mathrm{~b}$ & $14.9 \mathrm{~b}$ & $100 \mathrm{~b}$ & $317.2 \mathrm{a}$ & $96.2 \mathrm{a}$ & $27.0 \mathrm{~b}$ & $2.8 \mathrm{a}$ \\
\hline & NI:Si+ & $4.7 \mathrm{~b}$ & $75.9 \mathrm{~b}$ & $7.3 \mathrm{~b}$ & $15.1 \mathrm{~b}$ & $103 \mathrm{~b}$ & $317.0 \mathrm{a}$ & $95.8 \mathrm{a}$ & $26.2 \mathrm{~b}$ & $2.8 \mathrm{a}$ \\
\hline & NI:Wo & $8.4 \mathrm{a}$ & $69.1 \mathrm{~b}$ & $6.9 \mathrm{~b}$ & $13.6 \mathrm{~b}$ & $98 \mathrm{c}$ & $310.7 \mathrm{a}$ & $95.7 \mathrm{a}$ & $26.2 \mathrm{~b}$ & $2.7 \mathrm{a}$ \\
\hline ANOVA p & & $<0.001$ & 0.002 & $<0.001$ & $<0.001$ & $<0.001$ & $<0.001$ & $<0.001$ & $<0.001$ & $<0.001$ \\
\hline
\end{tabular}

Within columns, content values followed by the same letter $(a, b, c)$ are not significantly different $(\mathrm{p}=0.05$, Tukey's mean separation test). $\mathrm{p}$ values within the various amendments are given through a one-way analysis of variance (ANOVA)

* TRB is the sum of total contents $\left(\mathrm{cmol}_{\mathrm{c}} \mathrm{kg}^{-1}\right)$ of $\mathrm{Ca}, \mathrm{Mg}, \mathrm{Na}$ and $\mathrm{K}$ (Herbillon 1986)

As inferred from Table 3, the contents of $\mathrm{C}, \mathrm{N}$, and exchangeable cations were significantly higher in $\mathrm{CA}$ than in NI. As computed from $\mathrm{C}$ content, the content of organic matter was $5.7 \%$ in CA and $.0 .2 \%$ in NI. Both the Cambisol CA and the Nitisol NI were acid, desaturated soils characterized by low $\mathrm{pH}$ and base saturation. However, they markedly differed in their respective soil buffering capacity that amounted to 31 and $0.2 \mathrm{cmol}_{\mathrm{c}}$ $\mathrm{kg}^{-1}$ in CA and NI, respectively (Fig. 2). Biochar application resulted in a significant increase of $\mathrm{C}$ and $\mathrm{N}$ contents in both soils while Wo did not. All amendments led to a significant $\mathrm{pH}$ increase. That increase was below $0.65 \mathrm{pH}$ unit for Wo whatever the soil type, and for CA:Biochar mixtures. Yet in NI, the $\mathrm{pH}$ increase was

Table 3 Selected properties of soils (CA, NI) and soil:amendment mixtures: pH, total contents of C and N, Cation Exchange Capacity (CEC) and contents of exchangeable cations

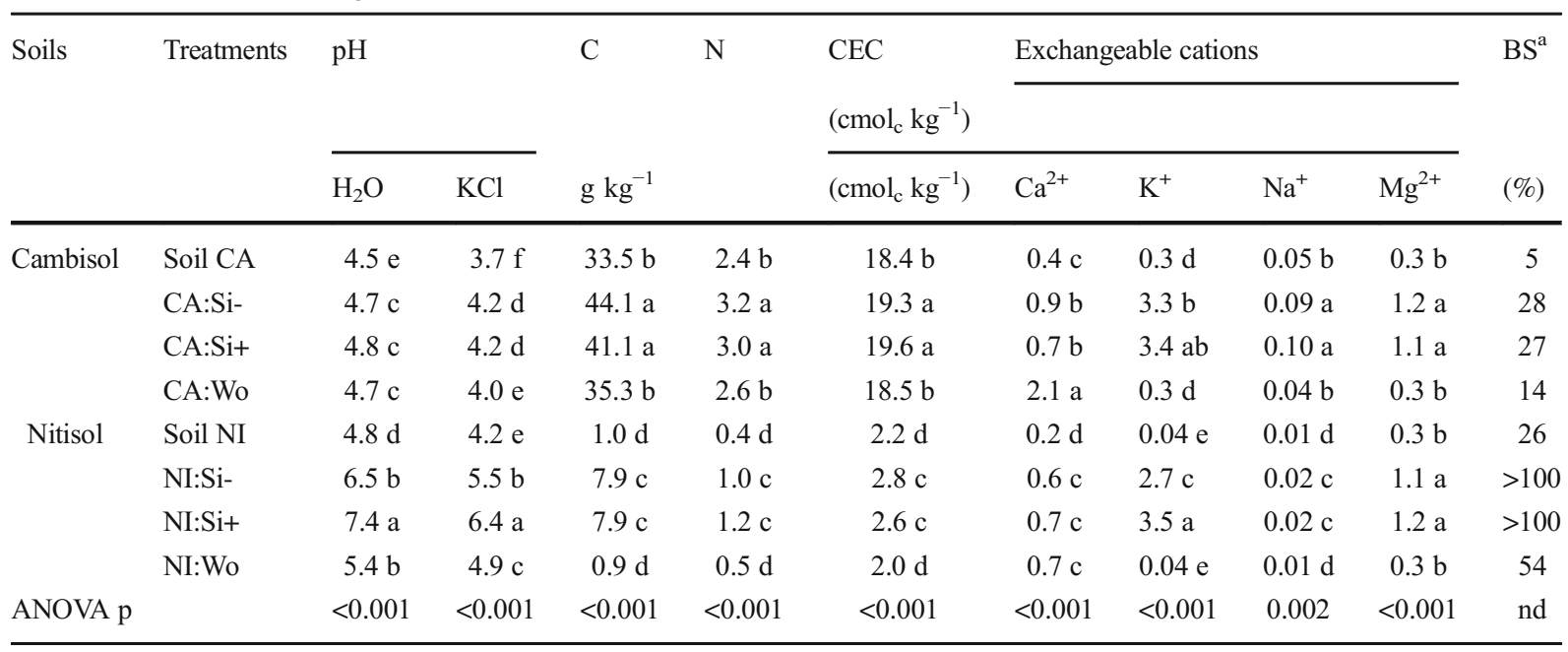

Within columns, mean values $(n=3)$ followed by the same letter $(a, b, c)$ are not significantly different $(p=0.05$, Tukey's mean separation test). $\mathrm{p}$ values within the various treatments are given through a one-way analysis of variance (ANOVA)

${ }^{a}$ Base Saturation: sum of the exchangeable cations as a percentage of CEC. The values above $100 \%$ are due to the release of $\mathrm{K}$ from biochar nd: not determined 


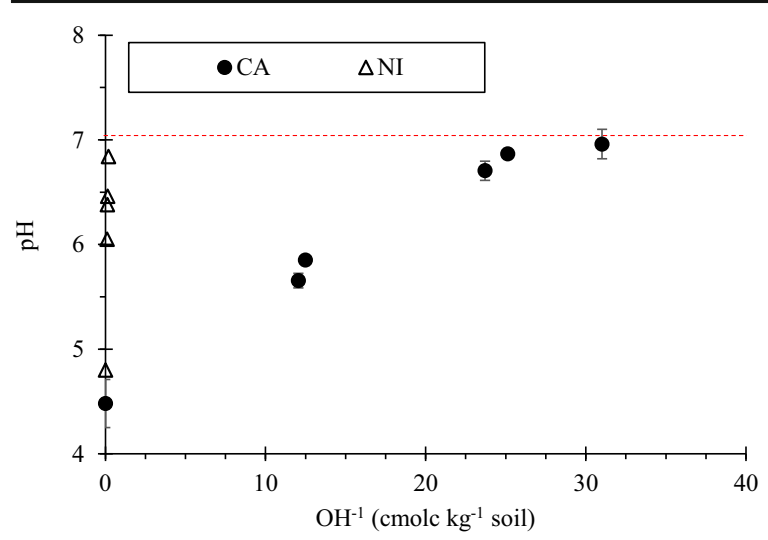

Fig. $2 \mathrm{pH}$ buffering capacity of the Cambisol (CA) and Nitisol (NI), as expressed by plotting $\mathrm{pH}$ against $\mathrm{OH}^{-}$addition. Error bars show \pm standard deviation $(n=4)$

particularly high after biochar application $(>1.7 \mathrm{pH}$ units). Both biochars Si- and $\mathrm{Si}+$ exhibited similar contents of ash, C, N, and other mineral elements (Table 1). Therefore, their respective applications on CA and NI had similar impacts on the properties of soil:biochar mixtures such as elemental contents (Table 2), pH, $\mathrm{C}$ and $\mathrm{N}$ content, and CEC (Table 3). Furthermore, the contents of exchangeable $\mathrm{K}^{+}, \mathrm{Na}^{+}, \mathrm{Ca}^{2+}$ and $\mathrm{Mg}^{2+}$ as well as base saturation increased in $\mathrm{CA}: \mathrm{Si}+, \mathrm{CA}: \mathrm{Si}-, \mathrm{NI}: \mathrm{Si}+$ and NI:$\mathrm{Si}-$, with respect to untreated soils $\mathrm{CA}$ and NI.

$\mathrm{Na}_{2} \mathrm{CO}_{3}$ extractable $\mathrm{Si}\left(\mathrm{Si}_{\text {alk }}\right)$ As shown in Fig. 3a, $\mathrm{Si}_{\text {alk }}$ decreased in the order $\mathrm{Si}+>\mathrm{Wo}>>\mathrm{Si}$-. In the Cambisol $\mathrm{CA}$ and CA:amendment mixtures (Fig. 3b), $\mathrm{Si}_{\text {alk }}$ did not significantly differ between CA, CA:Si- and CA:Wo; these contents were all below the one measured in CA:Si+. In the Nitisol NI and NI:amendment mixtures (Fig. 3c), the same trend was observed: $\mathrm{Si}_{\text {alk }}$ did not significantly differ between NI, NI:Si- and NI:Wo, but was much higher in $\mathrm{NI}: \mathrm{Si}+$.

$\mathrm{CaCl}_{2}$ extractable $\mathrm{Si}\left(\mathrm{CaCl}_{2}-\mathrm{Si}\right) \mathrm{CaCl}_{2}-\mathrm{Si}$ is usually measured in one extract after stirring for $16 \mathrm{~h}$ (Haysom and Chapman 1975; Sauer et al. 2006), 5 h (Henriet et al. 2008a; Houben et al. 2014) or $1 \mathrm{~h}$ (Korndörfer et al. 1999). In this study, we develop a novel kinetic methodology. The kinetic $\mathrm{CaCl}_{2}$ extraction of Si from amendments, soils and soil:amendment mixtures were performed for 128 days (Fig. 4). The $\mathrm{H}_{4} \mathrm{SiO}_{4}$ concentration of the $\mathrm{CaCl}_{2}$ extracts
Fig. 3 Contents of $\mathrm{Na}_{2} \mathrm{CO}_{3}$ extractable $\mathrm{Si}\left(\mathrm{Si}_{\text {alk }}, \mathrm{g} \mathrm{kg}^{-1}\right)$ of (a) the three amendments $(\mathrm{Si}-, \mathrm{Si}+$, and Wo), (b-c) the soils and soil amendment mixtures: (b) CA, $\mathrm{CA}: \mathrm{Si}-, \mathrm{CA}: \mathrm{Si}+$, and $\mathrm{CA}: \mathrm{Wo} ;(\mathbf{c})$ NI, NI:Si-, NI:Si+, and NI:Wo. Error bars show \pm standard deviation $(n=3)$. Lower case letters hold for each subgraph separately: amendments, Cambisol CA and CA: amendment mixtures, Nitisol NI and NI:amendment mixtures. Within each subgraph, values with the same lower case are not significantly different $(p=0.05$, Tukey's mean separation test), while different lower case letters indicate a significant $(p<0.05)$ difference. $p$ values are: $* \mathrm{p}<$ $0.05, * * p<0.01, * * * p<0.001$

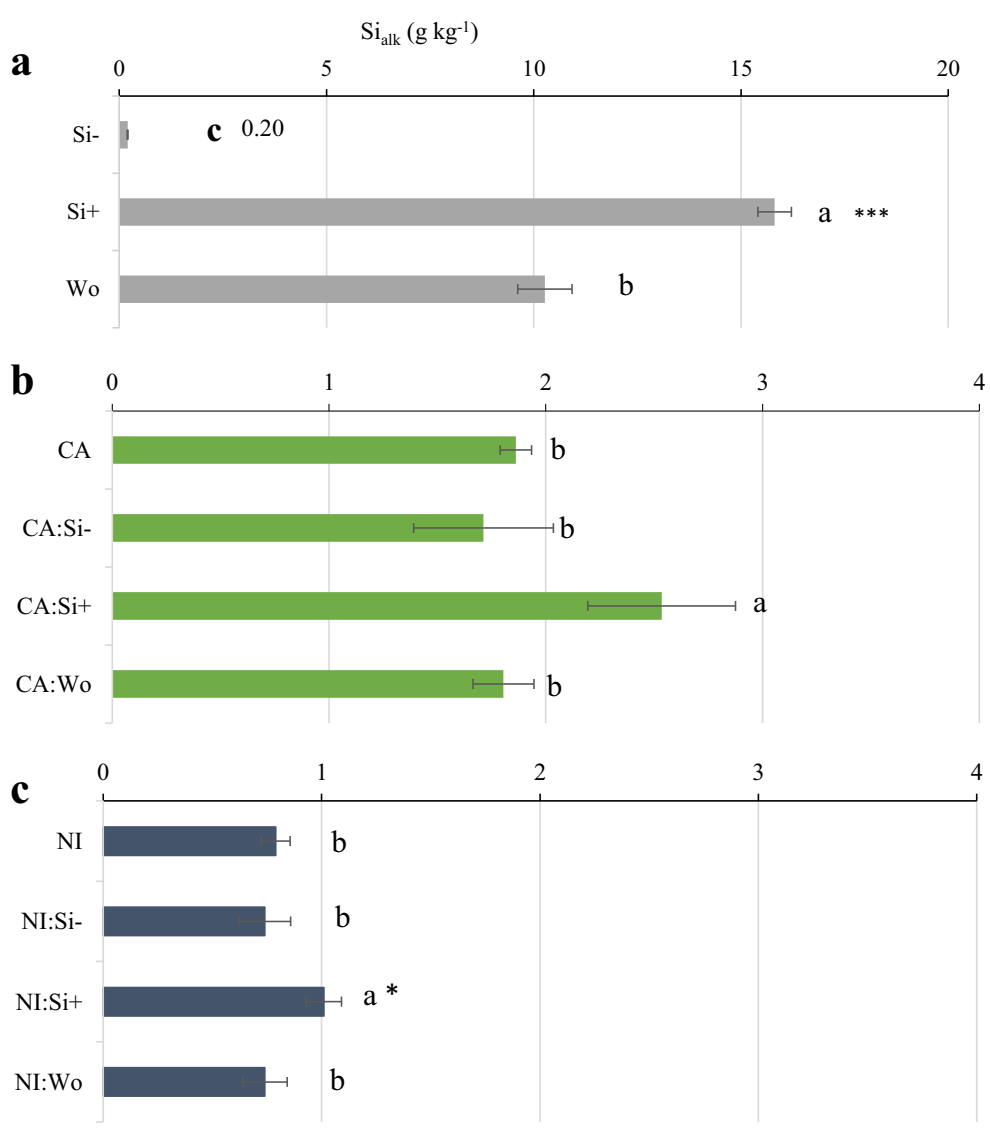


Fig. $4 \mathrm{CaCl}_{2}$ extractable $\mathrm{Si}$ content $\left(\mathrm{CaCl}_{2}-\mathrm{Si}\right)$ as plotted against time $(6 \mathrm{~h}, 12 \mathrm{~h}, 24 \mathrm{~h}$ (1 day), 2, 4, 8, 16, 32, 64 and 128 days. a: amendments $\mathrm{Si}$, $\mathrm{Si}+$ and Wo; b: CA, CA:Si-, $\mathrm{CA}: \mathrm{Si}+$ and CA:Wo; c. NI, NI:Si-, NI:Si + and NI:Wo. Note that the units of $\mathrm{CaCl}_{2}-\mathrm{Si}$ are $\mathrm{g} \mathrm{kg}^{-1}$ in (a) and $\mathrm{mg} \mathrm{kg}^{-1}$ in (b-c). Error bars show \pm standard deviation $(n=3)$
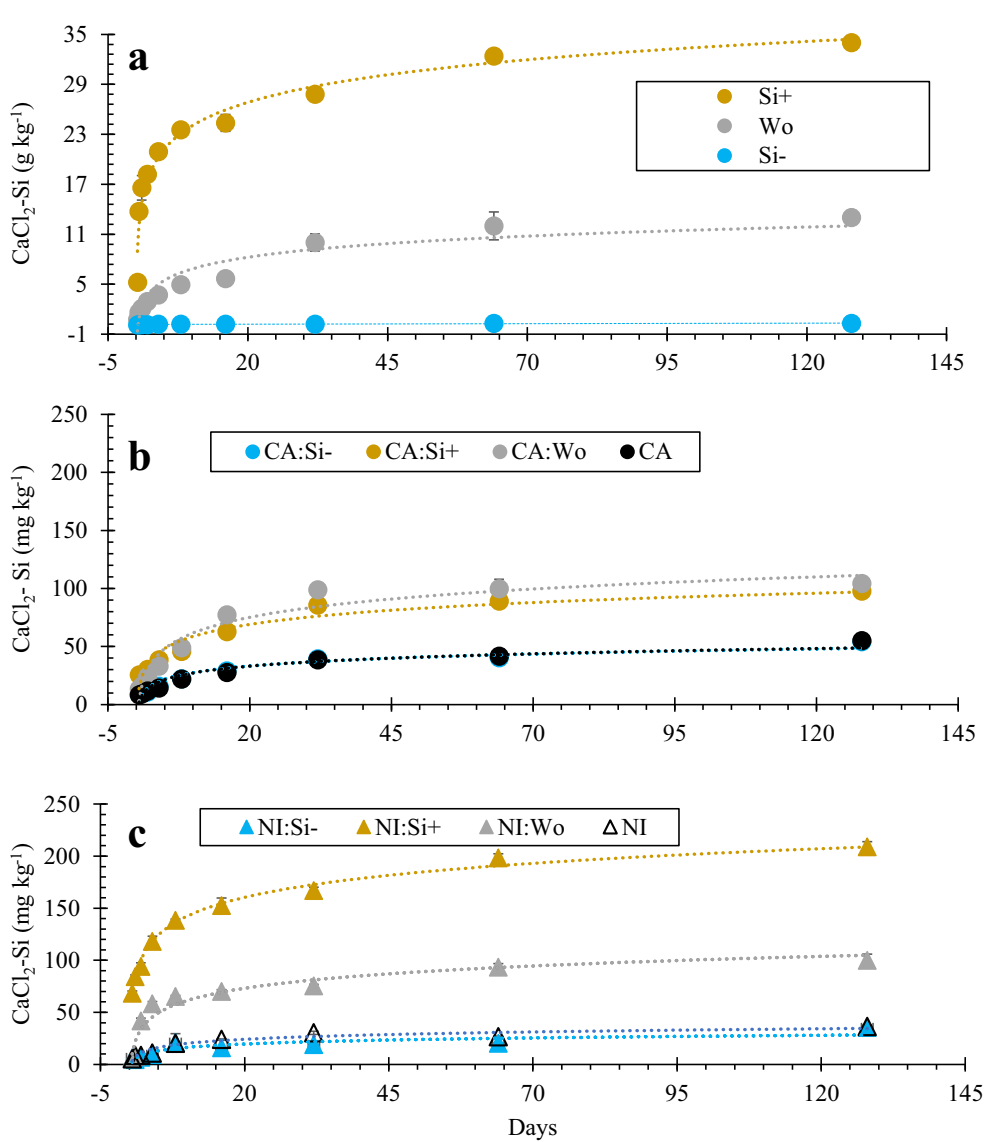

(Table S1) progressively increased with increasing time, from $10^{\text {to } 3.3}$ to $10^{-2.9} \mathrm{M}$ for $\mathrm{Si}$ - biochar, $10^{-1.3}$ to $10^{-0.97}$ $\mathrm{M}$ for $\mathrm{Si}+$ biochar, $10^{-2.2}$ to $10^{-1.3} \mathrm{M}$ for wollastonite. It increased with time from $10^{\text {to } 4.6}$ to $10^{-3.7} \mathrm{M}$ for both CA and $\mathrm{CA}: \mathrm{Si}-, 10^{-4.2}$ to $10^{-3.8} \mathrm{M}$ for $\mathrm{CA}: \mathrm{Si}+$, and $10^{-4.4}$ to $10^{-3.4} \mathrm{M}$ in CA:Wo. It also increased with time from $10^{\text {to }}$ ${ }^{4.8}$ to $10^{-3.9} \mathrm{M}$ in both NI and NI:Si-, $10^{-3.9}$ to $10^{-3.1} \mathrm{M}$ in $\mathrm{NI}: \mathrm{Si}+$, and $10^{-4.8}$ to $10^{-3.5} \mathrm{M}$ in NI:Wo. The strong and positive correlation $(\mathrm{r}=0.96)$ between $\mathrm{CaCl}_{2}-\mathrm{Si}$ at $128 \mathrm{~d}$ and $\mathrm{CaCl}_{2}-\mathrm{Si}$ at $16 \mathrm{~h}$ further illustrates the increase of $\mathrm{CaCl}_{2}$-Si with increasing time since the regression predicts that $\mathrm{CaCl}_{2}-\mathrm{Si}$ at $128 \mathrm{~d}$ is 2.6 times larger than that at $16 \mathrm{~h}$. As shown in Fig. 4, the Si release exhibited a classical parabolic shape followed by steady state, except for the Si- biochar. The slope of the Si release varied in sharpness according to the material tested. The release rate of $\mathrm{CaCl}_{2}-\mathrm{Si}$ was particularly sharp for $\mathrm{Si}+$ and Wo. After 128 days, the cumulative $\mathrm{CaCl}_{2}$-Si was two-fold higher in $\mathrm{Si}+$ than in Wo (Table 4; Fig. 4a). In contrast, $\mathrm{Si}$ - showed a negligible release of $\mathrm{CaCl}_{2}$-Si. As illustrated in Fig. $4 \mathrm{~b}$ and $3 \mathrm{c}$, the release of $\mathrm{CaCl}_{2}$-Si from CA and NI showed a similar trend: a slow release up to day 32 followed by a plateau. Yet, Si release at day 128 was much larger in CA than in NI (Table 4). The application of $\mathrm{Si}+$ biochar and Wo significantly increased the content of $\mathrm{CaCl}_{2}-\mathrm{Si}$ in both $\mathrm{CA}$ and NI. The cumulative content of $\mathrm{CaCl}_{2}$-Si at day 128 did not significantly differ between $\mathrm{CA}: \mathrm{Si}+$ and CA:Wo. However, this content was much larger in $\mathrm{NI}: \mathrm{Si}+$ than in NI:Wo.

The contents of total $\mathrm{Si}$, biogenic $\mathrm{Na}_{2} \mathrm{CO}_{3}$ extractable $\mathrm{Si}\left(\mathrm{Si}_{\mathrm{alk}}\right)$, and $\mathrm{CaCl}_{2}-\mathrm{Si}$ at day 128 in amendments and soil:amendment mixtures were compared in Table 4 to the efficiency of Si release $R_{S i}$, as computed using [Eq.3]. $R_{S i}$ of biochar Si- was negative in both soils. $R_{S i}$ of biochar $\mathrm{Si}+$ was lower in CA than in NI. However, $R_{S i}$ of Wo did not differ between CA and NI.

The $\mathrm{pH}$ dynamic during $\mathrm{CaCl}_{2}$ extraction did not differ between biochars and wollastonite (Fig. 5a). $\mathrm{CaCl}_{2}-\mathrm{pH}$ increased during the first 5 days, and further decreased to $\mathrm{CaCl}_{2}-\mathrm{pH}$ values ranging between 7.6 and 8.1 at day 128 . This $\mathrm{pH}$ evolution was also observed in soils and soil:amendment mixtures (Fig. 5b, c). However, the $\mathrm{CaCl}_{2}$-pH values were smaller than the ones measured for the amendments (Fig. 5a). They were below 4.8 in 
Table 4 Total contents of $\mathrm{Si}, \mathrm{Na}_{2} \mathrm{CO}_{3}$ extractable $\mathrm{Si}\left(\mathrm{Si}_{\text {alk }}\right)$, and $\mathrm{CaCl}_{2}$ extractable $\mathrm{Si}\left(\mathrm{CaCl}_{2}-\mathrm{Si}\right)$ contents (after 128 days) in the amendments, soils, and soil:amendment mixtures, as well as wheat shoot $\mathrm{Si}$ content, wheat shoot dry matter (DMs) and Si mineralomass in soil:amendment mixtures

\begin{tabular}{|c|c|c|c|c|c|c|c|c|}
\hline & Materials & $\begin{array}{l}\text { Total Si } \\
\mathrm{g} \mathrm{kg}^{-1}\end{array}$ & $\begin{array}{l}\mathrm{Si}_{\text {alk }} \\
\mathrm{g} \mathrm{kg}^{-1}\end{array}$ & $\begin{array}{l}\mathrm{CaCl}_{2}-\mathrm{Si}^{\dagger} \\
\mathrm{mg} \mathrm{kg}^{-1}\end{array}$ & $\begin{array}{l}\text { Efficiency of Si } \\
\text { release } R_{S i}^{\dagger \dagger} \\
\%\end{array}$ & $\begin{array}{l}\text { Shoot Si content } \\
\mathrm{g} \mathrm{kg}^{-1}\end{array}$ & $\begin{array}{l}\text { DMs } \\
\text { mg pot }^{-1}\end{array}$ & Si mineralomass \\
\hline \multirow[t]{3}{*}{ Amendements } & Si- & $0.31 \mathrm{c}$ & $0.20 \mathrm{c}$ & $0.31 \times 10^{3} \mathrm{c}$ & & & & \\
\hline & $\mathrm{Si+}$ & $51.28 \mathrm{~b}$ & $15.81 \mathrm{a}$ & $34.65 \times 10^{3} \mathrm{a}$ & & & & \\
\hline & Wo & $235.44 \mathrm{a}$ & $10.27 \mathrm{~b}$ & $13.69 \times 10^{3} \mathrm{~b}$ & & & & \\
\hline \multirow[t]{4}{*}{ Cambisol } & Soil CA & $270.8 \mathrm{~b}$ & $1.9 \mathrm{~b}$ & $55.1 \mathrm{~d}$ & $0 \mathrm{c}$ & $1.3 \mathrm{e}$ & $139.6 \mathrm{c}$ & $0.2 \mathrm{~d}$ \\
\hline & CA:Si- & $269.8 \mathrm{~b}$ & $1.7 \mathrm{~b}$ & $54.2 \mathrm{~d}$ & $+1+$ & $2.2 \mathrm{~d}$ & $149.3 \mathrm{bc}$ & $0.3 \mathrm{~d}$ \\
\hline & $\mathrm{CA}: \mathrm{Si}+$ & $272.5 \mathrm{~b}$ & $2.5 \mathrm{a}$ & $97.8 \mathrm{~b}$ & $5.3 \mathrm{~b}$ & $3.9 \mathrm{c}$ & $178.7 \mathrm{ab}$ & $0.7 \mathrm{c}$ \\
\hline & CA:Wo & $274.2 \mathrm{~b}$ & $1.8 \mathrm{~b}$ & $104.2 \mathrm{~b}$ & $6.1 \mathrm{~b}$ & $10.5 \mathrm{a}$ & $210.2 \mathrm{a}$ & $2.2 \mathrm{a}$ \\
\hline \multirow[t]{4}{*}{ Nitisol } & Soil NI & $317.2 \mathrm{a}$ & $0.8 \mathrm{~d}$ & $36.3 \mathrm{e}$ & $0 \mathrm{c}$ & $0.9 \mathrm{f}$ & $89.9 \mathrm{~d}$ & $0.08 \mathrm{e}$ \\
\hline & NI:Si- & $317.2 \mathrm{a}$ & $0.7 \mathrm{~d}$ & $35.3 \mathrm{e}$ & t†t & $1.9 \mathrm{~d}$ & $160.2 \mathrm{bc}$ & $0.3 \mathrm{~d}$ \\
\hline & NI:Si+ & $317.0 \mathrm{a}$ & $1.0 \mathrm{c}$ & $208.8 \mathrm{a}$ & $20.2 \mathrm{a}$ & $6.9 \mathrm{~b}$ & $198.7 \mathrm{a}$ & $1.4 \mathrm{~b}$ \\
\hline & NI:Wo & $310.7 \mathrm{a}$ & $0.7 \mathrm{~d}$ & $99.7 \mathrm{c}$ & $6.1 \mathrm{~b}$ & $12.0 \mathrm{a}$ & $134.9 \mathrm{bc}$ & $1.6 \mathrm{~b}$ \\
\hline ANOVA $p$ & & $<0.001$ & $<0.001$ & $<0.001$ & $<0.001$ & $<0.001$ & $<0.001$ & $<0.001$ \\
\hline
\end{tabular}

Within 'amendments' and 'soils and soil:amendment mixtures', means followed by the same letter are not significantly different ( $\mathrm{p}=0.05$, Tukey's mean separation test). $\mathrm{p}$ values within the various treatments are given through a one-way analysis of variance (ANOVA)

${ }^{\dagger} \mathrm{Si}$ amounts after 128-days of kinetic extractions (see Fig. 3)

${ }^{\dagger} R_{S i}$ computed from [Eq 1]

${ }^{\dagger \dagger}$ The computed value of $R_{S i}$ is negative because the amount of Si released from soil:Si- is below the one of Si released in untreated soils CA and NI

both soils $\mathrm{CA}$ and NI. Biochar and Wo applications increased $\mathrm{CaCl}_{2}-\mathrm{pH}$ values in $\mathrm{CA}$ and NI. In $\mathrm{CA}$ :amendment mixtures, $\mathrm{CaCl}_{2}$-pH slightly increased to 4.9-5.2 at day 5, and further decreased to 4.5-4.8 at day 128. In NI:Si- and NI:Si+, $\mathrm{CaCl}_{2}-\mathrm{pH}$ increased to 7.0-7.3 at day 5, then decreased to 6.8-7.0 at day 128. In $\mathrm{NI}: \mathrm{Wo}, \mathrm{CaCl}_{2}-\mathrm{pH}$ raised to 7.2 , and further slightly increased to 7.4 at day 128 . Noteworthy was the large difference of $\mathrm{CaCl}_{2}-\mathrm{pH}$ values between, on the one hand, CA:Wo, CA:Si- and CA:Si + (pH = 4.5-4.8 at day 128), and, on the other hand, NI:Wo, NI:Si- and NI:Si+, despite the fact that $\mathrm{CaCl}_{2}-\mathrm{pH}$ values were low and similar in both untreated soils at day 128 .

Biomass and Si mineralomass of wheat plants The values of the dry weight of wheat shoots at 32 days $\left(\mathrm{DM}_{\mathrm{S}}\right)$ are presented in Table $4 . \mathrm{DM}_{\mathrm{S}}$ was lower in NI than in CA. Wo significantly increased $\mathrm{DM}_{\mathrm{S}}$ in CA. Biochar applications significantly increased $\mathrm{DM}_{\mathrm{S}}$ in both $\mathrm{CA}$ and NI. Yet this effect was much larger for biochar $\mathrm{Si}+$ than for biochar Si-. As shown in Table 4, Si-, $\mathrm{Si}+$ and Wo increased the Si mineralomass of wheat shoots in both CA and NI. Shoot Si mineralomass increased in the following orders for the respective soils: $\mathrm{CA}=\mathrm{CA}: \mathrm{Si}-<$ $\mathrm{CA}: \mathrm{Si}+<\mathrm{CA}: \mathrm{Wo}$, NI < NI:Si- < NI:Si + = NI:Wo.

\section{Discussion}

Soil constituents and weathering stage The organic matter content was nearly 30 times larger in the Cambisol CA $(5.7 \%)$ than in the Nitisol NI $(0.2 \%)$. The soil mineralogical assemblage of CA was typical for a moderately weathered soil since it contains $\mathrm{Ca}$-, $\mathrm{Mg}-, \mathrm{K}$ - and Na-bearing primary minerals as well as 2:1 and 2:1:1 clay minerals. In contrast, that of NI was typical for a highly weathered soil as it contained kaolinite, Fe and Ti oxides, muscovite and quartz. The Total Reserve in Bases (TRB), which estimates the content of weatherable minerals (Herbillon 1986), amounted to 144 and $107 \mathrm{cmol}_{\mathrm{c}} \mathrm{kg}^{-1}$ in CA and NI, respectively (Table 2). In the Nitisol NI, K was by far the dominant cation in TRB (Table 2), confirming the presence of muscovite, a dioctahedral mica resistant to weathering in soils. Thus, the large amount of total K had "hidden" 
Fig. $5 \mathrm{pH}$ of the $\mathrm{CaCl}_{2}$ extract as plotted against time $(6 \mathrm{~h}, 12 \mathrm{~h}$, $24 \mathrm{~h}$ (1 day), 2, 4, 8, 16, 32, 64 and 128 days.). a: $\mathrm{Si}-, \mathrm{Si}+$ and Wo; b: CA, CA:Si-, CA:Si + and CA:Wo; c. NI, NI:Si-, NI:Si + and NI:Wo. Error bars show \pm standard deviation $(\mathrm{n}=3)$
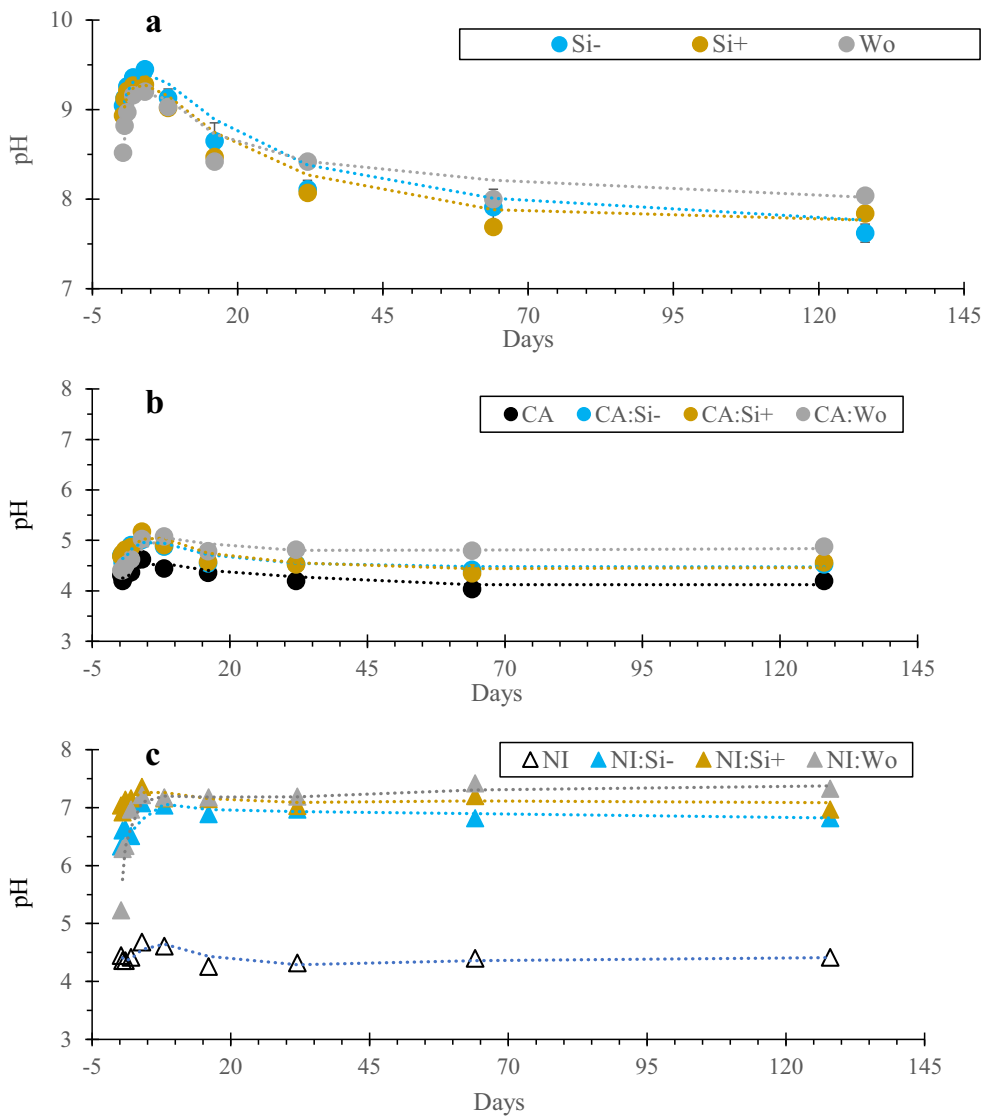

the advanced weathering stage of NI since muscovite does not weather in soils. The reserve of weatherable $\mathrm{Ca}, \mathrm{Mg}$, and $\mathrm{Na}$ minerals were estimated by the difference between TRB and the content of non-exchangeable $\mathrm{K}$ [total $\mathrm{K}$ - exchangeable $\mathrm{K}$ ] (Tables 2 and 3), thus excluding micaceous $\mathrm{K}$. In the Nitisol NI, [TRB - non exchangeable $\mathrm{K}$ ] amounted to $24 \mathrm{cmol}_{\mathrm{c}} \mathrm{kg}^{-1}$ which was far below the upper TRB limit of $40 \mathrm{cmol}_{\mathrm{c}} \mathrm{kg}^{-1}$ for highly weathered ferrallitic soils (Herbillon 1986). The Cambisol and the Nitisol thus largely differed in constitutive properties that explain the marked difference between their respective soil buffering capacity (Fig. 2) and CEC (Table 3). Assuming a CEC of $1.97 \mathrm{cmol}_{\mathrm{c}} \mathrm{kg}^{-1}$ per $1 \%$ C (Fig. 5b in Hardy et al. 2016), the contribution of organic matter amounted to 6.5 and $0.2 \mathrm{cmol}_{\mathrm{c}} \mathrm{kg}^{-1}$ in $\mathrm{CA}$ and NI respectively. In other words, clay minerals contributed to $65 \%$ and $78 \%$ of soil CEC in CA and NI respectively, and CEC majorly rules the soil buffering capacity. The wheat plantlets, which were grown in a soil:deionized water system, clearly responded to soil type and weathering stage since their biomass, Si content and mineralomass (Table 4) were all lower in NI than in CA. This observation accords with previous results showing that increasing soil weathering stage decreases Si plant content and mineralomass (Henriet et al. 2008b; Klotzbücher et al. 2016), as well as soil bioavailable Si content and BSi stock (Table 4) (Henriet et al. 2008a; Klotzbücher et al. 2015; Meunier et al. 2018).

Biogenic Si The higher BSi content in CA than in NI suggests that phytoliths are much less abundant in NI than in CA. The advanced weathering stage of the Nitisol and the absence of vegetation above that soil contribute to a low BSi content. Indeed, BSi particles return to soil through litterfall containing phytoliths in forest soils (Alexandre et al. 1997; Cornelis et al. 2011; Gérard et al. 2008; Meunier et al. 2008; Meunier et al. 1999; Sommer et al. 2013), in which phytoliths make the reactive BSi pool that contributes substantially to the DSi pool (Cornelis and Delvaux 2016). Adding Si + biochar significantly increased $\mathrm{Si}_{\text {alk }}$ in NI and CA compared to Si- biochar and Wo, because of the abundance of phytoliths in $\mathrm{Si}+$ biochar, and their absence in Wo 
and Si- biochar. Since the linear dissolution of Wo during the first $120 \mathrm{~min}\left(\mathrm{Si}_{\mathrm{alk}}=0.63 *\right.$ time +10.08 ; time $=1-5 \mathrm{~h}$; not illustrated) was similar to that described for primary lithogenic silicates (DeMaster 1981), $\mathrm{Si}_{\text {alk }}$ was not amorphous in Wo. In soils and soil:Wo mixtures, $\mathrm{Si}_{\text {alk }}$, as determined by the intercept on the Y axis at time zero (DeMaster 1981), did not differ between, respectively, CA:Wo and CA, and NI:Wo and NI (Fig. 2). These findings support the non-amorphous $\mathrm{Si}$ origin of $\mathrm{Si}_{\text {alk }}$ in Wo. They further show that the DeMaster technique, though widely used to quantify amorphous silica, was not specific to amorphous silica, and thus to phytoliths, because it dissolved wollastonite. In contrast, $\mathrm{Si}_{\text {alk }}\left(\mathrm{g} \mathrm{kg}^{-1}\right)$ was fully amorphous (of course biogenic), but negligible in Si- biochar (0.2), and abundant in $\mathrm{Si}+$ biochar (15.8). The application of the two biochars on both soils resulted in distinct effects on $\mathrm{Si}_{\text {alk }}$. Si- biochar did not increase the BSi pool in any soil, confirming the absence of phytoliths in $\mathrm{Si}$ biochar. The $\mathrm{Si}+$ biochar thus consisted of a major BSi supplier. $\mathrm{Si}_{\text {alk }}$ indeed increased by 1.3 in NI and 1.4 in $\mathrm{CA}$, supporting the argument that $\mathrm{Si}_{\text {alk }}$ in $\mathrm{Si}+$ biochar was fully amorphous and biogenic, and that phytolith particles present in biochar contributed to the BSi pool in soils. The addition of phytolithic biochar thus increased $\mathrm{Si}_{\mathrm{alk}}$ that is assumed to quantify the soil BSi pool.

Bioavailable Si Given the solubility of phytoliths (Fraysse et al. 2009), supplying BSi through phytolithrich biochar should increase the pool of bioavailable $\mathrm{Si}$, as measured through $\mathrm{CaCl}_{2}$ extraction in soil (Sauer et al. 2006). As inferred from Fig. 4, the rate of Si release decreased after 1-2 days, and became rather constant up to 128 days. The addition of biochar $\mathrm{Si}$ - did not increase $\mathrm{CaCl}_{2}$-Si in both soils (Table 4, Fig. 4). In contrast, the addition of $\mathrm{Si}+$ biochar largely increased the pool of bioavailable $\mathrm{Si}$, as previously shown for biochars derived from Miscanthus (Houben et al. 2014; Li et al. 2018), wheat (Liu et al. 2014), rice and switchgrass (Wang et al. 2018), likely because phytolith solubility increased after pyrolysis performed at $500{ }^{\circ} \mathrm{C}$. Xiao et al. (2014) have indeed shown that DSi release from rice-straw biochar was largely enhanced with increasing pyrolysis temperature in the range of $150-700{ }^{\circ} \mathrm{C}$, above which phytolith solubility decreased. However, soil type also affected Si bioavailability. Although $\mathrm{CaCl}_{2}-\mathrm{Si}$ $\left(\mathrm{mg} \mathrm{kg}^{-1}\right)$ content was much higher in $\mathrm{Si}+(34.7 \times$ $\left.10^{3}\right)$ than in Wo $\left(13.7 \times 10^{3}\right)$, it was lower in CA:Si +
(97.8) than in CA:Wo (104.2) (Table 4, Fig. 4). In contrast, $\mathrm{CaCl}_{2}-\mathrm{Si}\left(\mathrm{mg} \mathrm{kg}^{-1}\right)$ content was higher in $\mathrm{NI}: \mathrm{Si}+(208.8)$ than in NI:Wo (99.7). Furthermore, the positive impact of $\mathrm{Si}+$ biochar on $\mathrm{CaCl}_{2}-\mathrm{Si}$ was much larger in NI (208.8) than in CA (97.8). Thus, the effect of Si-rich biochar on Si bioavailability was soil-dependent. Phytolith solubility varies according to soil type (Bartoli and Wilding 1980) since soil constituents control the concentration of $\mathrm{H}_{4} \mathrm{SiO}_{4}{ }^{0}$ in given climatic conditions. Taking into account the fixed concentration of $\mathrm{Ca}^{2+}$ at $10^{-2} \mathrm{M}$, and concentrations of aqueous $\mathrm{H}_{4} \mathrm{SiO}_{4}{ }^{0}$ and $\mathrm{H}^{+}$(Table $\mathrm{S} 1$ ), our data suggest that the $\mathrm{H}_{4} \mathrm{SiO}_{4}{ }^{0}$ concentration at $128 \mathrm{~d}$ is controlled by clay minerals in non-amended soils (CA, NI), and by amorphous silica (phytolith) in the Nitisol NI amended with $\mathrm{Si}+$ biochar.

Phytolith solubility also largely depends on $\mathrm{pH}$ (Fraysse et al. 2006; Fraysse et al. 2009) and, consequently, on soil buffering capacity. Supporting this view, the efficiency of Si release $R_{S i}$ (Table 4 ) was 4 times larger in NI $(20 \%)$ than in CA $(5 \%)$. Four factors could have enhanced $R_{S i}$ in the Nitisol NI relatively to the Cambisol CA. Firstly, BSi minerals were present in the untreated Cambisol, but absent in the untreated Nitisol. In the former, native BSi minerals could have contributed to release $\mathrm{Si}$ during $\mathrm{CaCl}_{2}$ extraction, and therefore affected the dissolution rate of biocharphytolith or Wo. Secondly, Si could have been retrieved from the liquid phase through (i) the likely recombination of $\mathrm{Si}$ and $\mathrm{Al}$, and further formation of allophanic substances in the Cambisol CA (Farmer 1982), (ii) $\mathrm{H}_{4} \mathrm{SiO}_{4}{ }^{0}$ adsorption on $\mathrm{Fe}$ oxides (McKeague and Cline 1963; Delstanche et al. 2009; Meunier et al. 2018), which is enhanced in acidic conditions. The former process seems more likely given the availability of $\mathrm{Al}$ in the acidic Cambisol and its low $\mathrm{Fe}$ oxide content. The latter process is not favored in the Nitisol amended by $\mathrm{Si}+$ biochar because of high $\mathrm{pH}$. Thirdly, phytolith solubility in the Cambisol CA was limited by strong acidity (Fraysse et al. 2006). Indeed, pH only increased by 0.4 unit from 4.4 to $4.7-4.8$ after Wo and biochar addition in CA, whereas it increased from 4.8 in NI to 5.4 in NI:Wo, 6.5 in NI:Si-, and 7.4 in NI:Si + (Table 3). Indeed, at identical phytolith supply, pH controlled Si bioavailability and DSi as illustrated in Fig. 6a-b and (Fig. 6c), respectively. Our data corroborate the results of previous field studies (Miles et al. 2014; Li et al. 2018; Meunier et al. 2018; Klotzbücher et al. 2018; Haynes 2019), which highlight the positive relationship 

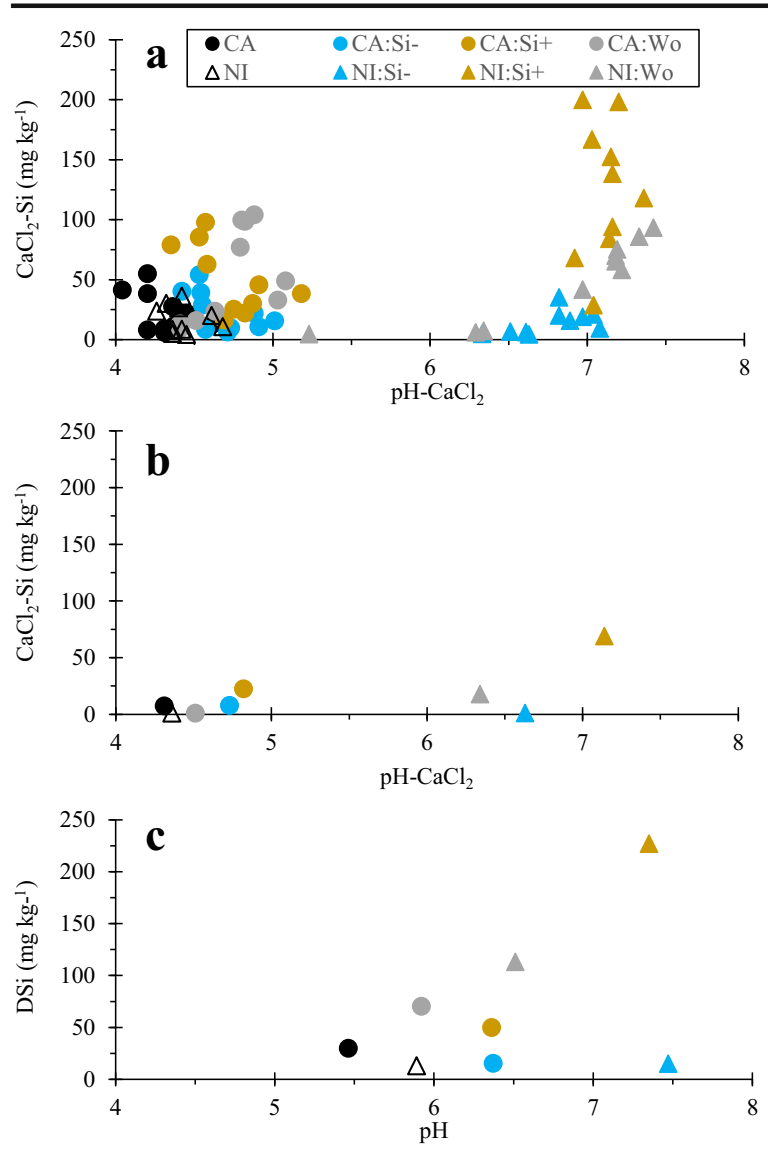

Fig. 6 Mobility of Si in the soil:solution system from three distinct experimental designs. (a) Plot of $\mathrm{CaCl}_{2}-\mathrm{Si}$ contents against $\mathrm{pH}-\mathrm{CaCl}_{2}$ of the extract, reporting all experimental points obtained at the 10 different extraction times $(6 \mathrm{~h}, 12 \mathrm{~h}, 1 \mathrm{~d}, 2 \mathrm{~d}, 4 \mathrm{~d}, 8 \mathrm{~d}, 16 \mathrm{~d}$, 32d, 64d, 128d) for the 8 "samples" (samples = soil; soil:Si-; soil:Si+; soil:Wo). (b) Plot of $\mathrm{CaCl}_{2}-\mathrm{Si}$ contents against $\mathrm{pH}-\mathrm{CaCl}_{2}$ of the extract, reporting experimental points obtained at the $16 \mathrm{~h}$ extraction time as computed from the curves shown in Fig. 4. (c) Plot of DSi against $\mathrm{pH}$ in the soil:solution:plant device before planting (1 week solid:solution equilibration)

between $\mathrm{pH}$ and $\mathrm{CaCl}_{2}$ extractable Si content after 5 or $16 \mathrm{~h}$ of extraction. Fourthly, the soil buffering capacity had alleviated the $\mathrm{pH}$ increase induced by amendments. In the Nitisol NI, a very small addition of $0.20 \mathrm{OH}^{-}$ $\mathrm{cmol}_{\mathrm{c}} \mathrm{kg}^{-1}$ is enough to increase $\mathrm{pH}$ from 4.8 to 7.0. As discussed above, the large difference between NI and CA (Fig. 2) was directly linked to soil constituents. The Cambisol CA contained relatively large amounts of organic matter $(\mathrm{OM})$ and high activity clays whereas the Nitisol NI was particularly poor in OM, and contained low activity clays. Therefore, the $\mathrm{pH}$-effect of wollastonite and biochars was much smaller in the highly buffered Cambisol than in the low buffered, highly weathered Nitisol.
The efficiency of Si release $\left(R_{S i}\right)$ followed the sequence: $\mathrm{NI}: \mathrm{Si}+(20 \%)>\mathrm{NI}:$ Wo $(6 \%)=\mathrm{CA}:$ Wo $(6 \%)=$ $\mathrm{CA}: \mathrm{Si}+(5 \%)$ (Table 4). Thus, biochar $\mathrm{Si}+$ was much more efficient in releasing bioavailable $\mathrm{Si}$ in NI than in CA, and more than Wo whatever the soil type. Phytoliths present in phytolith-enriched biochar were thus largely soluble. Phytoliths supplied bioavailable Si in quantities equivalent to those released by the inorganic fertilizer Wo in the moderately weathered Cambisol. In the highly weathered Nitisol, however, they supplied bioavailable $\mathrm{Si}$ in quantities four times larger than those released by Wo, since phytolith dissolution was strongly enhanced by the $\mathrm{pH}$ increase induced by biochar application. The release of bioavailable Si markedly increased above $\mathrm{pH} 7$, illustrating the major effects of $\mathrm{pH}$ and soil buffering capacity on phytolith dissolution. In particular, Figs. 2 and 6 highlight the potential to use Si-enriched biochar in highly weathered soils to boost Si biocycling, particularly if these soils have a small buffering capacity. The large liming effect of biochar due to the small soil buffering capacity of NI enhanced phytolith dissolution since increasing $\mathrm{pH}$ by 4 units, from 4.5 to 8.5 , increases the dissolution rate of phytoliths by two orders of magnitude (Fraysse et al. 2006; Fraysse et al. 2009).

Plant responses to wollastonite and biochar As expected, wheat shoot biomass was larger in the young Cambisol than in the highly weathered Nitisol, following a natural soil fertility gradient linked to weathering stage (Fig. 7). Applying amendments increased wheat shoot biomass in the following orders of increasing phytomass in the respective soils: $\mathrm{CA} \leq \mathrm{CA}: \mathrm{Si}-<\mathrm{CA}: \mathrm{Si}+\leq \mathrm{CA}: \mathrm{Wo}$; $\mathrm{NI} \leq \mathrm{NI}: \mathrm{Wo}<\mathrm{NI}: \mathrm{Si}-\leq \mathrm{NI}: \mathrm{Si}+$ (Fig. 7). The inorganic silicate fertilizer Wo had little significant effect in NI, but the largest one in CA. In the moderately weathered Cambisol CA, Wo addition alleviated mineral toxicities, as it does in other acid soils (Corrales et al. 1997; Keeping 2017; Liang et al. 2007) and increased plant biomass (Liang et al. 2015; Liang et al. 1994; Ma et al. 2006; Neu et al. 2017; Song et al. 2014). In contrast, biochar had a marked effect on biomass in NI. We attribute this difference to the overall increase of soil fertility after biochar application in the Nitisol. Biochar addition is known to increase soil $\mathrm{pH}$, plant nutrient availability and water retention (Biederman and Harpole 2013; Jeffery et al. 2011; Laird et al. 2010; Lehmann et al. 2003; Liang et al. 2006; Rondon et al. 2007; Yamato et al. 2006). As shown in this study, the application of $\mathrm{Si}-$ and $\mathrm{Si}+$ 
Fig. 7 Wheat shoot biomass as plotted against (a) soil $\mathrm{CaCl}_{2}$-Si at $16 \mathrm{~h}$ (b) $\mathrm{CaCl}_{2}-\mathrm{Si}$ at 128 days; Wheat shoot $\mathrm{Si}$ mineralomass as plotted against (c) soil $\mathrm{CaCl}_{2}$-Si at $16 \mathrm{~h}$ (d) $\mathrm{CaCl}_{2}-\mathrm{Si}$ at 128 days; Wheat shoot biomass (e) and its Si mineralomass (f) as plotted against its shoot $\mathrm{Si}$
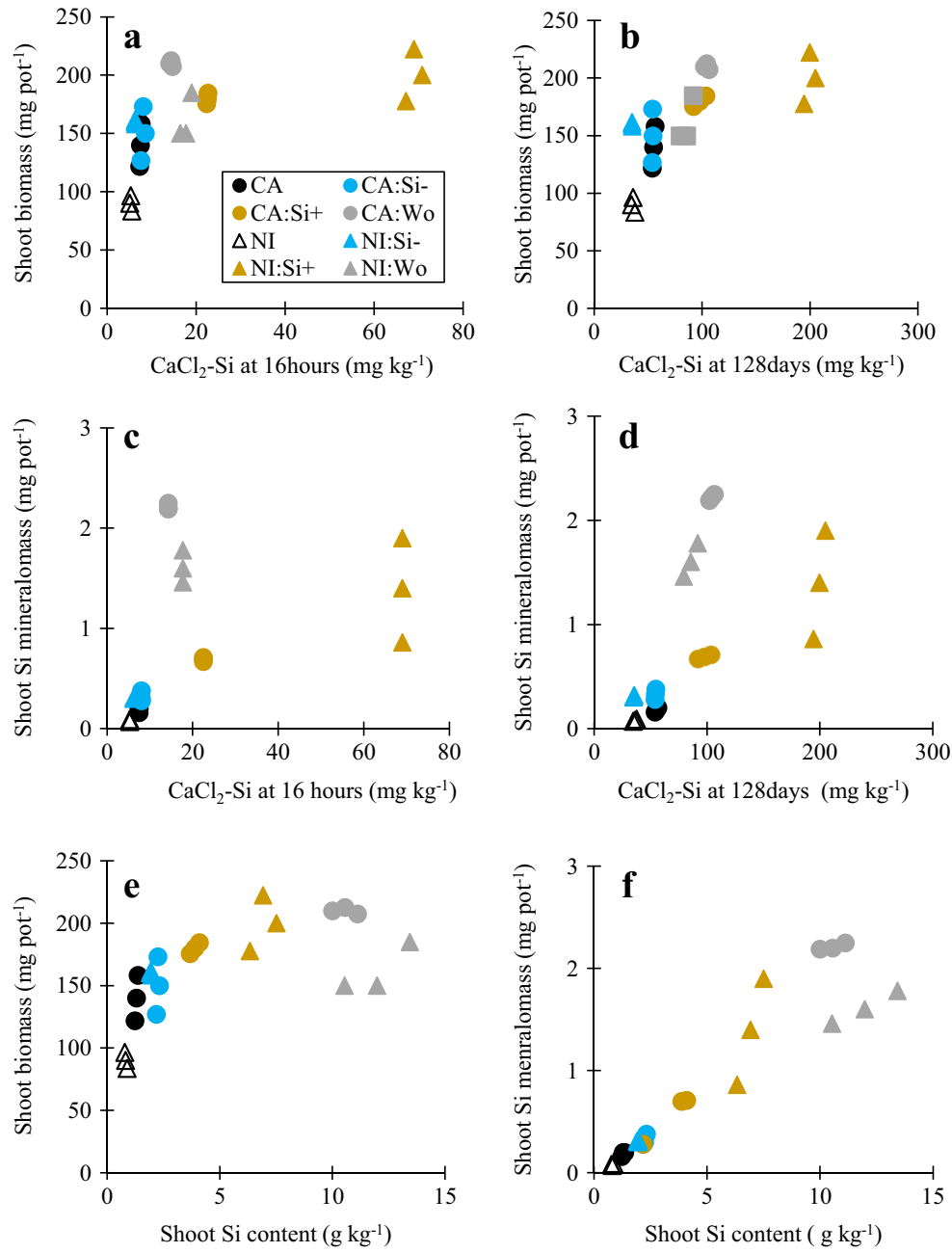

biochar significantly increased the soil contents of plant-available $\mathrm{Ca}, \mathrm{Mg}$ and $\mathrm{K}$ as well as of $\mathrm{C}$ and $\mathrm{N}$ (Table 3), and further increased the plant contents of $\mathrm{Ca}, \mathrm{Mg}$ and $\mathrm{K}$ (data not shown). The addition of biochar ( $\mathrm{Si}$ - and $\mathrm{Si}+$ ) increased the contents of exchangeable $\mathrm{K}$ and $\mathrm{Mg}$. Enhanced plant growth induced an increase of plant $\mathrm{Si}$ content and mineralomass even after biochar Si- addition in both soils, suggesting that the alkalinity of biochar partly led to elevate $\mathrm{Si}$ solubility. In addition, improved plant growth can induce rhizospheric mineral weathering through silicate dissolution (Hinsinger 1998). Noteworthy is the fact that, for both soils, biochar $\mathrm{Si}+$ largely increased wheat shoot biomass, Si content and mineralomass (Table 4). Thus, our data confirm the positive effects of biochar on soil fertility, on the one hand, and Si bioavailability on the other hand, promoting plant biomass. Furthermore, the relative impact of Si-enriched biochar on plant biomass, Si content and mineralomass was largest in the most weathered soil (NI). At identical supply of the two biochars ( $\mathrm{Si}+$ and $\mathrm{Si}-)$, which exhibit identical physico-chemical characteristics, wheat biomass was 1.2 fold larger in $\mathrm{CA}: \mathrm{Si}+$ and $\mathrm{NI}: \mathrm{Si}+$ than that in CA:Si- and NI:Si-. As illustrated in Fig. 7, shoot biomass, Si content and mineralomass positively responded to the size of the bioavailable $\mathrm{Si}$ pool in soils. It further suggests that supplying phytolithic biochar substantially increases shoot biomass, and promotes the biocycling of $\mathrm{Si}$ accumulated in crop straw residues. The latter may thus act as a sustainable $\mathrm{Si}$ source by reducing the loss of BSi out of croplands. Furthermore, the BSi pool was strongly impacted by the $\mathrm{pH}$ increase mediated by biochar addition in the poorly buffered Nitisol. In this respect, we further 
point out that the effect of liming on Si bioavailability depends on soil buffering capacity, which in turn depends on soil constituents, hence on soil development and weathering stage.

\section{Conclusion}

From the kinetic $\mathrm{CaCl}_{2}$-extraction carried out for 128 days, we conclude that the $\mathrm{CaCl}_{2}$-Si content at $128 \mathrm{~d}$ quantified the pool of bioavailable Si whereas the one performed at $16 \mathrm{~h}$ predicted it. This confirms the validity of $\mathrm{CaCl}_{2} 0.01 \mathrm{M}$ to extract plant available $\mathrm{Si}$ as a routine procedure at $16 \mathrm{~h}$. Though routinely used to quantify amorphous silica, notably phytolith, the DeMaster technique is not specific to amorphous silica since it dissolved wollastonite. Our data thus strengthen the role of phytoliths as a source of plant available Si, but question the DeMaster technique to quantify their pool.

Supplying Si through the addition of phytolithic biochar to soil increases plant available $\mathrm{Si}$ if $\mathrm{pH}$ conditions enhance phytolith solubility. Indeed, at identical phytolithic Si supply, soil pH and soil buffering capacity control the transfer of Si from soil to plant because the liming effect of biochar depended on soil buffering capacity. The Si soil-to-plant transfer is indeed largest in the poorly buffered, highly weathered Nitisol, in which phytolithic biochar performed better than wollastonite in terms of increased soil BSi and bioavailable Si contents, as well as increased Si uptake, plant shoot biomass and mineralomass.

The effect of phytolithic biochar on Si bioavailability is depending on soil constituents and properties, and consequently on soil type. The efficiency of Si fertilization is thus expected to be largely soil-dependent.

\footnotetext{
Acknowledgements We thank A. Iserentant and C. Givron for laboratory assistance (UCL), and M. Capelle for technical advice (UCL), as well as M. Pala for biochar preparation (Ghent University). Z. Li is supported by the 'Fonds Spécial de Recherche' of the UCL in 2014-2015 and the 'Fonds National de la Recherche Scientifique' (FNRS) of Belgium in 2015-2019. D.U.B would like to thank BELSPO for funding the project SOGLO (The soil system under global change, P7/24). We thank the reviewers for their helpful comments to improve the manuscript, and the Editorin-Chief for his pertinent advices. All authors contributed to paper writing and revision.
}

\section{Compliance with ethical standards}

Conflict of interest The authors declare that there are no conflicts of interest.

Publisher's note Springer Nature remains neutral with regard to jurisdictional claims in published maps and institutional affiliations.

\section{References}

Alexandre A, Meunier J-D, Colin F, Koud J-M (1997) Plant impact on the biogeochemical cycle of silicon and related weathering processes. Geochim Cosmochim Acta 61:677682

Bartoli F, Wilding L (1980) Dissolution of biogenic opal as a function of its physical and chemical properties. Soil Sci Soc Am J 44:873-878

Belanger RR (1995) Soluble silicon: its role in crop and disease management of greenhouse crops. Plant Dis 79:329-336

Berthelsen S, Noble AD, Garside AL (2001) Silicon research down under: past, present, and future. In Studies in Plant Science, vol 8. Elsevier, pp 241-255

Biederman LA, Harpole WS (2013) Biochar and its effects on plant productivity and nutrient cycling: a meta-analysis. GCB Bioenergy 5:202-214

Chao T, Sanzolone R (1992) Decomposition techniques. J Geochem Explor 44:65-106

Chapman HD (1965) Cation-exchange capacity. In: Black CA et al. (eds) Methods of soil analysis. Part 2, Chemical and microbiological properties. Agronomy, Madison, pp. 891901

Cornelis JT, Delvaux B (2016) Soil processes drive the biological silicon feedback loop. Funct Ecol 30:1298-1310

Cornelis J-T, Titeux H, Ranger J, Delvaux B (2011) Identification and distribution of the readily soluble silicon pool in a temperate forest soil below three distinct tree species. Plant Soil 342:369-378

Corrales I, Poschenrieder C, Barceló J (1997) Influence of silicon pretreatment on aluminium toxicity in maize roots. Plant Soil 190:203-209

Datnoff LE, Heckman JR (2014) Silicon fertilizers for plant disease protection. World Fertilizer Congress

Delstanche S, Opfergelt S, Cardinal D, Elsass F, André L, Delvaux B (2009) Silicon isotopic fractionation during adsorption of aqueous monosilicic acid onto iron oxide. Geochim Cosmochim Acta 73(4):923-934

DeMaster DJ (1981) The supply and accumulation of silica in the marine environment. Geochim Cosmochim Acta 45:17151732

Epstein E (1994) The anomaly of silicon in plant biology. Proc Natl Acad Sci 91:11-17

Exley C (1998) Silicon in life: a bioinorganic solution to bioorganic essentiality. J Inorg Biochem 69:139-144 
Farmer VC (1982) Significance of the presence of allophane and imogolite in Podzol Bs horizons for podzolization mechanisms: a review. Soil Sci Plant Nutr 28(4):571-578

Fraysse F, Pokrovsky OS, Schott J, Meunier J-D (2006) Surface properties, solubility and dissolution kinetics of bamboo phytoliths. Geochim Cosmochim Acta 70:1939-1951

Fraysse F, Pokrovsky OS, Schott J, Meunier J-D (2009) Surface chemistry and reactivity of plant phytoliths in aqueous solutions. Chem Geol 258:197-206

Garrels RM, Christ CL (1965) Solutions, minerals, and equilibria. Harper Row, New York, p. 46

Gérard F, Mayer K, Hodson M, Ranger J (2008) Modelling the biogeochemical cycle of silicon in soils: application to a temperate forest ecosystem. Geochim Cosmochim Acta 72: 741-758

Glaser B, Lehmann J, Zech W (2002) Ameliorating physical and chemical properties of highly weathered soils in the tropics with charcoal-a review. Biol Fertil Soils 35(4): 219-230

Guntzer F, Keller C, Poulton PR, McGrath SP, Meunier J-D (2012) Long-term removal of wheat straw decreases soil amorphous silica at Broadbalk, Rothamsted. Plant Soil 352:173-184

Hardy B, Cornelis JT, Houben D, Lambert R, Dufey JE (2016) The effect of pre-industrial charcoal kilns on chemical properties of forest soil of Wallonia, Belgium. Eur J Soil Sci 67: 206-216

Haynes RJ (2014) A contemporary overview of silicon availability in agricultural soils. J Plant Nutr Soil Sci 177:831-844

Haynes RJ (2017) The nature of biogenic Si and its potential role in Si supply in agricultural soils. Agric Ecosyst Environ 245: $100-111$

Haynes RJ (2019) What effect does liming have on silicon availability in agricultural soils? Geoderma 337:375-383

Haynes RJ, Belyaeva O, Kingston G (2013) Evaluation of industrial wastes as sources of fertilizer silicon using chemical extractions and plant uptake. J Plant Nutr Soil Sci 176:238248

Haysom M, Chapman L (1975) Some aspects of the calcium silicate trials at Mackay. Proceedings

Henriet C, Draye X, Oppitz I, Swennen R, Delvaux B (2006) Effects, distribution and uptake of silicon in banana (Musa spp.) under controlled conditions. Plant Soil 287:359-374

Henriet C, Bodarwé L, Dorel M, Draye X, Delvaux B (2008a) Leaf silicon content in banana (Musa spp.) reveals the weathering stage of volcanic ash soils in Guadeloupe. Plant Soil 313:71-82

Henriet C, De Jaeger N, Dorel M, Opfergelt S, Delvaux B (2008b) The reserve of weatherable primary silicates impacts the accumulation of biogenic silicon in volcanic ash soils. Biogeochemistry 90:209-223

Herbillon A (1986) Chemical estimation of weatherable minerals present in the diagnostic horizons of low activity clay soils. Proceedings of the 8th International Clay Classification Workshop: Classification, Characterization and Utilization of Oxisols (part 1)[Beinroth, FH, Camargo, MN and Eswaran (ed)][39-48](Rio de Janeiro, 1986)

Hinsinger P (1998) How do plant roots acquire mineral nutrients? Chemical processes involved in the rhizosphere. Adv Agron 64:225-265

Houben D, Sonnet P, Cornelis J-T (2014) Biochar from Miscanthus: a potential silicon fertilizer. Plant Soil 374: 871-882
IUSS (2014) World reference base for soil resources 2014 international soil classification system for naming soils and creating legends for soil maps. FAO, Rome

Jeffery S, Verheijen FG, Van Der Velde M, Bastos AC (2011) A quantitative review of the effects of biochar application to soils on crop productivity using meta-analysis. Agric Ecosyst Environ 144:175-187

Jones L, Handreck K (1965) Studies of silica in the oat plant. Plant Soil 23:79-96

Keeping MG (2017) Uptake of silicon by sugarcane from applied sources may not reflect plant-available soil silicon and total silicon content of sources. Front Plant Sci 8:760

Keeping MG, Miles N, Rutherford RS (2017) Liming an acid soil treated with diverse silicon sources: effects on silicon uptake by sugarcane (Saccharum spp. hybrids). J Plant Nutr 41:273287

Keller C, Guntzer F, Barboni D, Labreuche J, Meunier J-D (2012) Impact of agriculture on the Si biogeochemical cycle: input from phytolith studies. Compt Rendus Geosci 344:739-746

Kelly EF (1990) Methods for extracting opal Phytoliths from soil and plant material. Document of the Department of Agronomy, Colorado State University

Kittrick, J. A. (1977). Mineral equilibria and the soil system. In: Dixon JB and Weed SB (eds) Minerals in Soil Environments. Soil Sci Soc Am, pp. 1-25

Klotzbücher T, Marxen A, Vetterlein D, Schneiker J, Türke M, van Sinh N, Manh NH, van Chien H, Marquez L, Villareal S (2015) Plant-available silicon in paddy soils as a key factor for sustainable rice production in Southeast Asia. Basic Appl Ecol 16:665-673

Klotzbücher T, Marxen A, Jahn R, Vetterlein D (2016) Silicon cycle in rice paddy fields: insights provided by relations between silicon forms in topsoils and plant silicon uptake. Nutr Cycl Agroecosyst 105:157-168

Klotzbücher T, Klotzbücher A, Kaiser K, Merbach I, Mikutta R (2018) Impact of agricultural practices on plant-available silicon. Geoderma 331:15-17

Koning E, Epping E, Van Raaphorst W (2002) Determining biogenic silica in marine samples by tracking silicate and aluminium concentrations in alkaline leaching solutions. Aquat Geochem 8:37-67

Korndörfer GH, Coelho NM, Snyder GH, Mizutani CT (1999) Avaliação de métodos de extração de silício em sols cultivados com arroz de sequeiro. Rev Bras Cienc Solo 23(1):101-106

Laird DA, Fleming P, Davis DD, Horton R, Wang B, Karlen DL (2010) Impact of biochar amendments on the quality of a typical Midwestern agricultural soil. Geoderma 158:443-449

Lehmann J, Joseph S (2015) Biochar for environmental management: science, technology and implementation. Science and technology. Earthscan, London

Lehmann J, da Silva JP Jr, Steiner C, Nehls T, Zech W, Glaser B (2003) Nutrient availability and leaching in an archaeological Anthrosol and a Ferralsol of the Central Amazon basin: fertilizer, manure and charcoal amendments. Plant and Soil 249:343-357

Li Z, Delvaux B, Yans J, Dufour N, Houben D, Cornelis J-T (2018) Phytolith-rich biochar increases cotton biomass and silicon-mineralomass in a highly weathered soil. J Plant Nutr Soil Sci 181:537-546 
Liang YC, Ma TS, Li FJ, Feng YJ (1994) Silicon availability and response of rice and wheat to silicon in calcareous soils. Commun Soil Sci Plant Anal 25:2285-2297

Liang B, Lehmann J, Solomon D, Kinyangi J, Grossman J, O'neill B, Skjemstad J, Thies J, Luizao F, Petersen J (2006) Black carbon increases cation exchange capacity in soils. Soil Sci Soc Am J 70:1719-1730

Liang Y, Sun W, Zhu Y-G, Christie P (2007) Mechanisms of silicon-mediated alleviation of abiotic stresses in higher plants: a review. Environ Pollut 147:422-428

Liang Y, Nikolic M, Bélanger R, Gong H, Song A (2015) Silicon in agriculture: from theory to practice. Springer, Netherlands

Liu X, Zhang A, Ji C, Joseph S, Bian R, Li L, Pan G, Paz-Ferreiro J (2013) Biochar's effect on crop productivity and the dependence on experimental conditions - a meta-analysis of literature data. Plant Soil 373:583-594

Liu X, Li L, Bian R, Chen D, Qu J, Wanjiru Kibue G, Pan G, Zhang X, Zheng J, Zheng J (2014) Effect of biochar amendment on soil-silicon availability and rice uptake. J Plant Nutr Soil Sci 177:91-96

Lucas Y (2001) The role of plants in controlling rates and products of weathering: importance of biological pumping. Annu Rev Earth Planet Sci 29:135-163

Lucas Y, Luizao F, Chauvel A, Rouiller J, Nahon D (1993) The relation between biological activity of the rain forest and mineral composition of soils. Science 260:521-523

Ma JF, Takahashi E (2002) Soil, fertilizer, and plant silicon research in Japan. Elsevier, Amsterdam

Ma JF, Tamai K, Yamaji N, Mitani N, Konishi S, Katsuhara M, Ishiguro M, Murata Y, Yano M (2006) A silicon transporter in rice. Nature 440:688-691

McKeague J, Cline M (1963) Silica in soil solutions: II. The adsorption of monosilicic acid by soil and by other substances. Can J Soil Sci 43:83-96

Meunier JD, Colin F, Alarcon C (1999) Biogenic silica storage in soils. Geology 27:835-838

Meunier J, Guntzer F, Kirman S, Keller C (2008) Terrestrial plantSi and environmental changes. Mineral Mag 72:263-267

Meunier JD, Sandhya K, Prakash NB, Borschneck D, Dussouillez $\mathrm{P}$ (2018) $\mathrm{pH}$ as a proxy for estimating plant-available Si? A case study in rice fields in Karnataka (South India). Plant Soil 432(1-2):143-155

Miles N, Manson AD, Rhodes R, Van Antwerpen R, Weigel A (2014) Extractable silicon in soils of the south African industry and relationships with crop uptake. Commun Soil Sci Plant Anal 45:2949-2958

Neu S, Schaller J, Dudel EG (2017) Silicon availability modifies nutrient use efficiency and content, C: N: P stoichiometry, and productivity of winter wheat (Triticum aestivum L.). Sci Rep 7:40829

Riotte J, Sandhya K, Prakash NB, Audry S, Zambardi T, Chmeleff J, Buvaneshwari S, Meunier JD (2018) Origin of silica in rice plants and contribution of diatom earth fertilization: insights from isotopic Si mass balance in a paddy field. Plant Soil 423(1-2):481-501
Rondon MA, Lehmann J, Ramírez J, Hurtado M (2007) Biological nitrogen fixation by common beans (Phaseolus vulgaris L.) increases with bio-char additions. Biol Fertil Soils 43:699708

Ronsse F, Van Hecke S, Dickinson D, Prins W (2013) Production and characterization of slow pyrolysis biochar: influence of feedstock type and pyrolysis conditions. GCB Bioenergy 5(2):104-115

Saccone L, Conley D, Sauer D (2006) Methodologies for amorphous silica analysis. J Geochem Explor 88:235-238

Sauer D, Saccone L, Conley DJ, Herrmann L, Sommer M (2006) Review of methodologies for extracting plant-available and amorphous $\mathrm{Si}$ from soils and aquatic sediments. Biogeochemistry 80:89-108

Smithson F (1956) Plant opal in soil. Nature 178:107

Sohi S, Krull E, Lopez-Capel E, Bol R (2010) A review of biochar and its use and function in soil. Adv Agron 105:47-82

Sommer M, Jochheim H, Höhn A, Breuer J, Zagorski Z, Busse J, Barkusky D, Meier K, Puppe D, Wanner M (2013) Si cycling in a forest biogeosystem-the importance of transient state biogenic Si pools. Biogeosciences 10:4991-5007

Song Z, Wang H, Strong PJ, Shan S (2014) Increase of available soil silicon by Si-rich manure for sustainable rice production. Agron Sustain Dev 34:813-819

Thiry M, Quesnel F, Yans J, Wyns R, Vergari A, Theveniaut H, Simon-Coinçon R, Ricordel C, Moreau M-G, Giot D (2006) Continental France and Belgium during the early cretaceous: paleoweatherings and paleolandforms. Bull Soc Geol Fr 177: $155-175$

Titeux H, Delvaux B (2009) Experimental study of DOC, nutrients and metals release from forest floors developed under beech (Fagus sylvatica L.) on a Cambisol and a Podzol. Geoderma 148:291-298

Unzué-Belmonte D, Struyf E, Clymans W, Tischer A, Potthast K, Bremer M, Meire P, Schaller J (2016) Fire enhances solubility of biogenic silica. Sci Total Environ 572:1289-1296

Vandevenne F, Struyf E, Clymans W, Meire P (2012) Agricultural silica harvest: have humans created a new loop in the global silica cycle? Front Ecol Environ 10:243-248

Wang M, Wang JJ, Wang X (2018) Effect of KOH-enhanced biochar on increasing soil plant-available silicon. Geoderma 321:22-31

Xiao X, Chen B, Zhu L (2014) Transformation, morphology, and dissolution of silicon and carbon in rice straw-derived biochars under different pyrolytic temperatures. Environ Sci Technol 48:3411-3419

Yamato M, Okimori Y, Wibowo IF, Anshori S, Ogawa M (2006) Effects of the application of charred bark of Acacia mangium on the yield of maize, cowpea and peanut, and soil chemical properties in South Sumatra, Indonesia. Soil Sci Plant Nutr 52:489-495

Yoshida S (1981) Fundamentals of rice crop science. International Rice Research Institute, Los Baños, Laguna, Philippines 